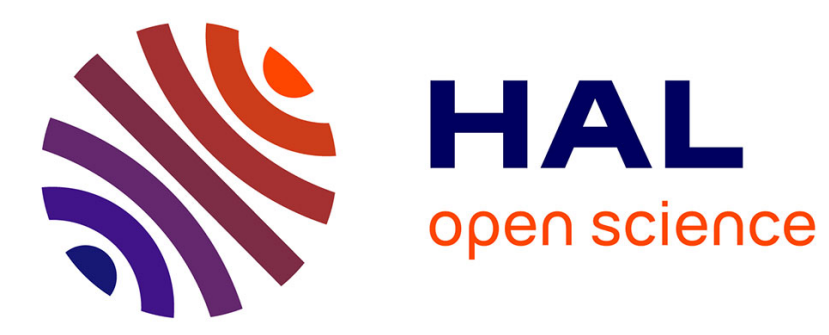

\title{
Uṇhissavijjaya in Cambodia: Rituals and Narrative
}

Olivier de Bernon

\section{To cite this version:}

Olivier de Bernon. Uṇhissavijjaya in Cambodia: Rituals and Narrative. International Journal of Buddhist Thought and Culture, 2020, 30 (2), pp.109-146. 10.16893/IJBTC.2020.12.31.2.109 . hal03132915

\section{HAL Id: hal-03132915 \\ https://hal.science/hal-03132915}

Submitted on 5 Feb 2021

HAL is a multi-disciplinary open access archive for the deposit and dissemination of scientific research documents, whether they are published or not. The documents may come from teaching and research institutions in France or abroad, or from public or private research centers.
L'archive ouverte pluridisciplinaire HAL, est destinée au dépôt et à la diffusion de documents scientifiques de niveau recherche, publiés ou non, émanant des établissements d'enseignement et de recherche français ou étrangers, des laboratoires publics ou privés. 


\title{
Uṇhissavijjaya in Cambodia: Rituals and Narrative
}

\author{
Olivier de BERNON
}

Born in 1957, Olivier de Bernon holds a PhD in Philosophy (1984), and a PhD in Far-Eastern Studies (2000). He runs a manuscript conservation project in Cambodia since 1990 in the framework of the French School for Far-Eastern Studies (École française d'Extrême-Orient) where he is now professor. He has been in charge of the personal archives of King Norodom Sihanouk, of which he published the inventory in 2010. Promoted to General Curator of Heritage, he headed Musée National des Arts Asiatiques Guimet, in Paris, from 2011 to 2013. His current work and his seminar at the École des Hautes Études focus mainly on ancient legal literature from Southeast Asia (Cambodia and Siam).

Email: femc.efeo@wanadoo.fr

International Journal of Buddhist Thought \& Culture Vol. 30. No.2 (December 2020):109-146

(C) 2020 Academy of Buddhist Studies, Dongguk University, Korea

https://doi.org/10.16893/JJBTC.2020.12.31.2.109

The day of submission: 2020.10 .30 .

Completion of review: 2020.12.11.

Final decision for acceptance: 2020.12.28. 


\begin{abstract}
The core of this paper is the translation of a short Cambodian manuscript entiteled Sec-ktī jīv-dān (The gift of life). In the narrative of this text the Lord Buddha tells how a devaputta called Supatitthita, should recite the stanzas of the Unhissavijjaya in order to avoid the fate of falling into hell after his time in heaven is finished. The Lord Buddha even gives some instructions about how some rituals should be performed when reciting these stanzas. Though the manuscript of the Sec-ktī jīv-dān is quite rare nowadays in Cambodia, the ceremony of the gift of life (puny jīv-dān) involving the ritualized recitation of the Unhissavijjaya stanzas is not in Cambodia.
\end{abstract}

Key words: Uṇhissavijjayagāthā, Cambodian Buddhism, rituals, ceremony of the gift of life (puṇy jīv-dān), Parittasamodhānapālī (a collection of formulas of protection) 


\section{Introduction}

In a reluctant footnote, the editor of the Parittasamodhannapāli ${ }^{1}$ a collection of "formulas of protection" (parittas) designed for the Dhammayuttika fraternity that is active in Cambodia, explains that, though the text entitled Jivadanapattha-which is one of the titles used in Cambodia for the Unhissavijjayagätha-could not be found in any canonical sources, because of the great favour it has enjoyed for ages among the elders in this country, it should nevertheless be inserted among this collection of classical pieces of protective literature.

Such hesitation by a "scholarly correct" editor very well illustrates the difference that often exists between what is officially taught, and what is actually practiced, and chanted, by the Khmer Buddhist community. Indeed, the Unhissavijjayagatth $\bar{a}$ is a crucial text, chanted during one of the most commonly performed rituals, held, in addition to the usual monthly or yearly rituals, either in monasteries or in the homes of devotees. This ritual is called the "ceremony to increase one's lifespan" (bidhi puny camprön brah janmāyu), ${ }^{3}$ or more commonly the "ceremony of the gift of life" (puny jiv-dann).

This ceremony is performed, most often, to bring merit to its sponsor, the "master of the merit" (mcäs' puny), who, beside the "advantages" (änisansa) acquired in organizing a religious ceremony involving the presence of monks, expects to restore, maintain, or better his own health. In some cases, a group of people join together to organize the rite for the benefit of others; for example, rites are organized by children and grandchildren for the benefit of their parents and grandparents, or for the lay community of a village in order to benefit an especially venerated monk. (Sometimes, the same ritual, sponsored by the beneficiary himself, is set up in order to restore his wealth or his reputation. It would then be called sütr mant ramtoh groh " "recitation to destroy ill-fortune.")

Quite often, the puny jiv $v$-dann is part of a day-long ceremony that includes the very sophisticated ritual of the cand suk giri sütr, a rite involving the construction of a large labyrinth made of sand mounds enclosed within a fence that represents the boundaries of the world. Monks and laypeople then walk through this labyrinth to perform a form of initiatory symbolic journey to accumulate religious merit.

Most of the time, the puny jiv-dann is completed with the performance of the ritual of the "great tearing of the shroud" (bidhi chāk maha painskūl), during 
which the performer, most often (but not always) a monk, tears off a piece of cloth with which a member of the faithful, prostrate on the floor, has covered himself, thereby enacting both the meritorious deed of taking a shroud and making a robe from it-as commanded by the ascetic practice of the dutaiga (pansukülikanga) - and the tearing of the placental envelope, thus being reborn as a new and purified being, following a quite common obstetrical metaphor in Khmer Buddhism.

As sophisticated as traditional Cambodian Buddhist rituals are-involving elements such as the making, correct placement, and the use of precise and complicated objects; the orderly alternation of chants by monks and laypeople; and the construction of a particular form of pavilion-their procedures are typically not recorded in any traditional manual. The "liturgy" rests instead within the collective memory of the community. Therefore, these rituals, which follow unwritten patterns passed from generation to generation through practice and imitation, may differ considerably from performance to performance, depending on the wealth of the organizing committee or the location.

In this respect, the puny jiv-dān is a remarkable exception. Most of the practical elements of this ritual are mentioned in the text of the Sec-ktī jävdàn, the vernacular version of the Uinhissavijjayasutta translated into Khmer. Some of its different practical dispositions are even reported to have originated in the teachings of the Lord Buddha himself. For example, not only is the Buddha supposed to have uttered the stanzas of the Unhissavijjayagāth $\bar{a}$, he is also credited with having specified the making of various peculiar objects called for in the rite, such as life-sized shapes of a human body made from unhusked rice-called the "shape of life" (rüp-jivit)—and candles of pure beeswax measured to the height of the beneficiary of the rite.

\section{The Rituals of the "Gift of Life" (Jivit dān) as Practiced in Cambodia}

The puny jiv-dàn (ceremony of the gift of life) always begins in the middle of the afternoon, and proceed in the following manner:

Like most rituals in Cambodia, it begins with an invocation of local earthly spirits, the anak tā /neak tal, in particular their chief, Krun Bālì a näga king reported, in Khmer mythology, to have been the master of waters 
and earth before the triumph of the Buddha. This "rite for Krun Bālī" (bìdhi krun bäli), is a very common rite organized at the beginning of, but in a sense on the fringes of, almost any great Buddhist ritual. It is meant to propitiate the ground where the rituals are performed. Monks are not involved in this rite; instead, the acāry (a lay ritual specialist) of the monastery alone recites the appropriate formulas.

Then the monks proceed with the usual "salutation to the Triple Gem" (namassakār brah ratana trai), "request for the five precepts" (bidì süm sìl prām), and the "ritual of anointing with holy water" (bidhi sroc dik) for the beneficiaries of the ceremony. This sophisticated part of the ritual is held in a palatial "pavilion made with carved banana trees" (puspuk cāk'cek), an appellation which is sometimes used to name the whole ceremony, known as puny puspuk.

Only then can the "ceremony of the gift of life" (puny jiv-dān) begin, properly speaking. A senior acāry lights the "candle [measured to] the height" (dien jambar), a candle measured to the standing height of the beneficiary from the ground to the top of his head; the "candle [measured] when seated" (dien panguy); and the "candle [measured from shoulder to] shoulder" (dien smā) as it is prescribed by the Buddha himself, according to the text of "The Gift of Life" (Sec-ktī jìv-dān).

After this, one or four or seven monks are invited to recite the "formulas of protection" (parittas), including that of the "recitation to destroy ill-fortune" (sütr mant ramịtoh groh), borrowed from the Ațānätiyā Sutta:

\section{tehitvam rakkbito santo muto sabbabhayehi ca...}

By these Buddhas, may you be protected so that you may be liberated from all calamities.

Having recited these stanzas, the venerable monks next begin the recitation of the Unhissavijjayagath $\bar{a}$. In principle, they repeat the formula one hundred and eight times, though most of the time they recite the complete stanzas only once, and then chant a shorter text, consisting of nine stanzas that declare the Buddha, the Dhamma, and the Sangha to be "the supreme medicine, above all other medicines," thirty to forty times. 


\begin{tabular}{|c|c|}
\hline sakkatvā buddharatanam & osatham uttamam varam \\
\hline bitaṃ devamanussānaṃ & buddhatejena sottbinā \\
\hline nassantupaddavā sabbe & dukkhā vüpasamentu te \\
\hline sakkatvā dhammaratanam & osatham uttamam varaṃ \\
\hline parilā̄ūpasamanam & dhammatejena sotthinā \\
\hline nassantupaddavā sabbe & bhaā vūpasamentu te \\
\hline sakkatvā samgharatanam & osatham uttamam varam \\
\hline āhuneyyam pābuneyyam & samghatejena sotthinā \\
\hline nassantupaddavā sabbe & rogà vūpasamentu te. \\
\hline
\end{tabular}

Having revered the Buddha-Treasure, truly the best of medicines, Welfare for Devas and men, by the Buddhas's might may safety be; May all distress be destroyed, and all your suffering be stilled.

Having revered the Dhamma-Treasure, truly the best of medicines, Calmer of fevered passions, by the Dhamma's might may safety be; May all distress be destroyed and all your fears be stilled.

Having revered the Sangha-Treasure, truly the best of medicines, Worthy of gifts and hospitality, by the Sangha's might may safety be; May all distress be destroyed and all your ills be stilled.

Then begins the ritual of the "great tearing of the shroud" (bidhi chāk maba pansk $\bar{u}$ l) where the beneficiary is to remain prostrated on the floor, holding his hands joined in respect above the silhouette of his own body made of unhusked rice, the rup-jivit, and covering himself with the same piece of white cloth (sambat'sa) that covers it. A monk then slowly tears the cloth toward himself reciting three times:
aciram vatayam kāyo
pathavim adhisessati
chuddho apetaviñ̃āno
niratthamva kalingaram. [repeated three times]

Before a long time has passed, alas, this body will lie on the ground, rejected, without consciousness, just like a useless piece of wood. 
and the formula of Anumodanä:

yathā vārivāhà pürä paripürenti sāgaram (...)

Just as the rivers full of water fill the ocean full (...)

When the chāk mahā panskiul is over, the group of monks start the long recitations consisting in "elevating the light" (sütr lök räsì), beginning with Iti pi so bhagavä brah ädity, brah cand, brah angār devā... and proceeding with various stanzas of victory. Then the beneficiary of the ceremony "ritually offers to the monks" (pragén) the unhusked rice with which his rüp jivit was made. At the end of these long recitations, the party of laypeople attending the ceremony shoot off a festive round of firecrackers.

When all this comes to a close, a monk is "invited to make a prediction" (nimand samtèn darm desanā). Most of the time, nowadays, this sermon would be made extemporaneously (mät' dade), ${ }^{4}$ based on the inspiration of the preaching monk. Only the most traditional monks would, on this occasion, read the text of the Sec-ktī jiv-dān, that is the narrative of Suppatitthita devabutta, as an ànisamsa.

The ceremony extends through the night, ending only the next morning, with the ritual of "honouring the elders and closing the ceremony" bidhi târ bistär chlan puny. It is worth noting that the use of certain ritual objects, such as the rüpjivit, is not limited to the "ceremony of the gift of life" (puny jiv-dann); for example, they are also used in the very traditional "ceremonies of monastic ordination" (puny pampuos näg). Indeed, the use of ritual items constructed following the measurements of the bodies of members of the Buddhist faithful is not at all unique in Khmer Buddhist liturgies. Very sophisticated objects of devotion, made of folded banana leaves, called pāsi dham /baysey thom/, are used during the closing rituals marking the end of certain phases of apprenticeship within the "old tradition of meditation," the kammatțhan pürān. These bāsi dham, shaped after measuring the height of the "meditating person," the yogavacār, are symbolically "ordained" (pampuos), in order that they may represent the person in some stage of the rituals. 


\section{Presentation of the Text}

Four different forms, or versions, of the Unhissavijjaya are found in Cambodian manuscript collections. The most common is a simple transcription of the stanzas of the Unhissavijjaya in Pāli, without an accompanying narrative. This version is always inscribed as a short manuscript called vān/vien/, usually with the title Jivadana or Jividanaparitta; it is almost always associated with another text, the Mahāmetrī (or Mettisütra).

The second version, also entirely in Pāli, is entitled Uṇissavijayasutta. It begins with the narrative in which the Buddha recommends that the Devaputta Supatitthita should recite the verses of the Unbissavijjaya in order to extend his life in the Tavatimsa Heaven. To date, only one copy of this version has been found. Since this text never circulated in Cambodia, it was most probably copied in Bangkok at the request of the École française d'ExtrêmeOrient at the beginning of the twentieth century to complete the collections of the Buddhist Institute in Phnom Penh.

The two remaining versions are written in Khmer. They are both quite rare today, bearing the same title Sec-kti jiv-dan ("Concerning the Gift of Life"). They are very close to each other in terms of form and content. One version is twenty-four folios long, the other fifteen. To date, we have found in Cambodia only two copies of each of these versions. They both give the Supatitthita narrative in Khmer and the Pāli Unhissavijjaya stanzas with glosses in Khmer. The structures of the narrative are almost the same, though the longer version emphasizes the "advantages" (anisamsa) obtained when freeing two- and fourfooted creatures from bondage. Only the shorter version, which is translated below, provides practical details for the organization of the ritual to be performed during the recitation. ${ }^{5}$

One should emphasize the conformity of the Khmer story of Supatitthita devaputta, not only unsurprisingly with the Pāli version as known in Thailand, but also with the Chinese narratives, translated from Indian Sanskrit, dating from even before the tenth century. Indeed, it must be stressed that, while its recitation seems to have been lost for centuries in India and in China, and for decades in Thailand ${ }^{6}$, its recitation and enactment remain very much a living tradition in Cambodia.

The Khmer text of "The Gift of Life" (Sec-ktī jìv-dān) is intertwined with short Pāli fragments of sentences, and sometimes with isolated Pāli words 
glossed in Khmer. Since there was no point in translating the same text twice, I have just included the embedded Pāli fragments as they appear in the original text.

\section{Translation}

"The Gift of Life" (Sec-ktī jìv-dān)

[1-a] namotassa bhagavato arahatto sammäsambuddhassa . ekasmim kira samaye satthà devatimnisabhavane viharanto päritachattakamüle mahipandalakamūlè sisane nisīdi dassasa/hassalokadhātu bisanipatitvā sabbedevā / namahāmayādevā puttassapamukhä abhidhammasanganī adhika sattakaranam abhidhammakathesi. bho sädhuvo...

O kind hearted men, as many as you are, so have we heard this: one day satthā the August One-Who-is-a-Sublime-Master for all of us, sojano devaputo both divinities and men, as many as we are, during the time when the Buddha was alive, ${ }^{7}$ the August Lord had risen up to the Heaven of the Thirty-Three. He had entered the Buddhist lent.

The August Master ${ }^{8}$ rested on the throne of stone of His Lordship Indra, king of kings, in the shade of the tree parijāta, that is a roluos paong tree, ${ }^{9}$ whose leaves are yellow like the flower of champa, and which is fifty yojana ${ }^{10}$ high and [1-b] sixty yojana ${ }^{11}$ wide. As for this stone seat, it is as soft as cotton that would have been carded seven times a day. When Lord Indra, king of kings, sits on his throne, the stone of which it is made bends to the heights of his hips. When the god gets up to depart, this stone resumes its form.

tad $\bar{a}$ At that time, the Lord Buddha-Who-is-Our-Precious-Master rested on the throne of stone that Lord Indra, king of kings, had offered him. Thus, the Master-of-the-Three-Worlds preached the Sublime Law which is contained in the seven books of the Abhidhamma, from the first one, which is the Classification of Things (Dhammasanganin), until the last one, [which] is the Great Treaty of Causalities (Mahäpatthanna), so that all divinities, as many as they were, among which Mahāmāyā, the mother of the Buddha, Indra and tadā E kodeva brahma, all the most prominent deities could listen.

The Master preached for three months without ever interrupting his discourse, speaking with a harmonious and ringing voice, ${ }^{12}$ powerful, profound, and flowing like the rain falling from heaven. 
tadā E kodeva [2-a] putto sapatițthitānāma ahosi tad̄̄ There was then a devaputta ${ }^{13}$ named Supatitthita who was reborn in the Heaven of the Thirty Three. Indeed, he had acquired [in his previous existences] so much merit that he enjoyed precious treasures in a palace fifteen yojana high, having a suite of a thousand young girls to serve him and to take care of him in this palace.

All these young girls knew how to make music with the five instruments ${ }^{14}$ to please this devaputta. However, this divine being, at that time, was not aware of his own age, nor of the moment when he should leave this paradisiacal world. tadā E ko àkāssaparitanāmadevaputto while at the same time, all the gods knew it well. canava äkässaparini All of those who resided in this divine abode were aware, and knew that the time of Supatitthita had come to an end.

[2-b] These devaputtas, as many as they were, gathered to reflect. devaputtabbümari dassasattame desenā toputtomanabanta dukkham anubhavanto Then they went together to speak to His Supreme Lordship Indra, the king of the gods, so that he would know that there was nothing left of the remaining time for Supatițthita. Then His Supreme Lordship Indra, the king of the gods, said to all divine beings, as many as they were:

O, gods, as many as you are, $\mathrm{O}$ gods do you know? In seven days Supatițhita will fall from this paradise and he will be born in hell avici $i^{15}$ where he will endure miserable suffering for many lifetimes and for a thousand hellish years. ${ }^{16}$ When he reaches the end of his time in hell, he will be reborn successively under the aspect of seven wild beasts: he will be born under the aspect of a turtle, the aspcet of a pig, of an owl, of a vulture, of a crow, of a dog, and of a cat. Then he will be born again [3-a] a thousand times from a woman's womb under the aspect of a deaf man, a dumb person, and a blind man.

atarapāyitisotassavacanam sutvā kapanohadayosovaputto The divine beings reported all this to Supatițhita. Atarapāyitisotassavacanam sutvā kapanohadayo sovaputto Only then did he know what His Supreme Lordship Indra, the king of the gods, had revealed, that his age would be neither happy nor stable. His heart was filled with fear, tadā kime Evarüppanna Uppatthavobhavisanti filled with deepest anxiety. He was completely devastated, his body full of anguish.

tadā kime Evarüppāna Uppatthavobhavisanti Then, Supatițhita, full of fear and of the greatest amazement, thought: 
How could I get out of the fatality of reaching the end of this divine age that is mine? pubbanimittam $\mathrm{O}$ impermanence in which $\mathrm{I}$ am! Have I no refuge nor help? pubbanimittam All the warning signs associated to the end of my age appear on me: the first is that my clothing [3-b] and my complexion are tarnished; the flowers that are my ornaments wither and scatter; my aura disappears; sweat oozes from my body, which is getting dreadful; my daybed, finally, becomes hard and uncomfortable, very different from what it used to be. O impermanence in which I am! Born among divine beings, having exhausted my time, I must leave this divine paradise full of all kinds of beauties. $\mathrm{O}$ charming servants, my lovers, here we are attanopubbanimittam disvā bhavisanti sariratosedopañcatisariraducuti separated because my misdeeds take me away from you. attanopubbanimittam disvā bhavisanti sariratosedo pañcati sariraducuti samdevaputtedhammam. 5 samderaputtedhammam These five warning signs appearing on my body, the very same appearing on all the divinities who must leave this [4-a] paradise. So it is.

The devaputta, having had these thoughts, clasped his hands above his head, bowed to greet His Supreme Lordship Indra, the king of the gods bho devaräja tvam mesāmipatisaranamkarohi ahammedivase cuto then sat down where he was prostrated, and he addressed His Supreme Lordship Indra, the king of the gods, as follows:

bho devarāja tvam mesāmipatisaraṇaṃkarohi ahaṃmedivase cutoavicinirayenibbato tatha banivassasahassāna ahantam dukkham anubhavisāmi. bhoavicinirayenibbato tatha banivassasahassāna ahantam dukkham anubhavisāmi. bho O king of the gods, in truth Supreme Lord Indra, king of the gods, Sovereign tvam tatha mahārāj the highest of all gods, tvam tathā mahārāja in truth, great king who is my refuge, as for me, only seven days remain before I have to leave this divine heavenly place. After that, I will be reborn in the hell avici to experience the most miserable pain during a thousand hellish years [4-b] as You told me.

natthi me saparāyanodevovattanāsetṭho devarājā sapatitvam hisetṭolokasmim nāham devohiddhiko ${ }^{17}$ tilokemaingalasel ttho lokapäpampāvāhano Then he recited the following formula: 
Truly Precious Being, among the divine and human beings, as many as they are, there is no one equal to you, my Master, sutvā sakodevarāj, immense in the powerful merits of your perfections, your sublime power which is my refuge.

Then His Supreme Lordship Indra, the king of the gods, having heard the words that Supatitthita had pronounced, spoke the following formula:

aham setṭholok smim näham devo mahiddhikotiloke mangalasețtho lokapäpampavähano [5-a] As for me, though being the greatest and most sublime being in the Three Worlds, my clairvoyance and my might are powerless to purify the faults of the beings who inhabit these Three Worlds. lokanatttham thapetvā Annam passāmimañgalam sabhäram nikonätțho lokabitā sano anuthasisampadāanuttaro devanañca hitatthāya-desanā... [But] $\mathrm{O}$ devaputta, I think that, in all these Three Worlds, if there is only one Sublime Person, [that might have these powers] it must be the August-who-has-merits, our Master, the August who teach the wisdom of his divine foreknowledge, the August Buddha, the One-who-is-in-truth-above-all-the-worlds. The August One is the refuge of these Three Worlds. so bhagava $\mathrm{He}$ is always with efficiency the refuge of all living beings, as many as they are, of all men, of all divine beings, of all the Indras and Brahmas. so bhagava $\bar{a}$ [5-b] The Buddha-who-is-theMaster shines with the radiance of six colors, more beautiful than anything in the world, and no one can compare to him. He can erase all the shortcomings and all the faults that exist in these worlds. Now, at this very moment, the August One has come to preach in our paradise tasmā in order that, we could all approach his place of rest, and seek refuge by him, the Buddha-who-is-theMaster.

so deva putto When he heard the words of His Supreme Lordship Indra, Supatitthita had the heart exalted by faith. First, he provided himself with candles, incense sticks, garlands of Jasmine flowers, then he set off, accompanying His Supreme Lordship Indra. tasmanno They entered the resting place of the August-and-Meritorious yenabhagavā. His Supreme Lordship Indra went to where the August Buddha-Who-is-the-Master was. [6-a] Having entered this place, he raised his joined hands in greetings and bowed to pay homage with candles, incense sticks and garlands of Jasmine flowers, then he sat down tadā bhante bhagavā in a decent way. tadā Then His Supreme 
Lordship Indra addressed the August-and-Meritorous One in these terms:

bhante bhagavā In truth, August-and-Meritorious One, O My Precious Master, this devaputta named Supatitthita, at the end of the next seven days, will fall from our paradise and will enter into hell avici to experience the pain corresponding to his demerits. So, he implores You, August, to tell us the supreme wisdom.

Then the August-and-Meritorious One answered His Supreme Lordship Indra's question, so that he would know, and He stated:

sobbajāto Ekasmim ki-[6-b]lesu jethako ahosi tasmäbijam Supreme Lord, O Supreme Lord, this devaputta, during a previous existence, this devaputta was born into the family of a very great hunter. He [himself] hunted endlessly all kinds of beasts that he killed for food. bhagava $\mathrm{It}$ is because of these evil actions that he has to be reborn in the form of a turtle, a pig, and a dog.

Then His Supreme Lordship Indra said:

bhante bhagavā In truth, somahäräjapubbejāto antamakkhipiyo August Onewho-has-Merits, this devaputta will be reborn in the form of beasts because of his bad actions. somahärājapubbejāto antamakkbipiyol tegahetvā ${ }^{18}$ tasmā pubbojätobha-vissatti O Supreme Lord, this devaputta, during a previous existence, never stopped capturing animals for food, snatching them from their mother's nest [7-a]. Because of this, he must be reborn in the form of wild beasts.

Then His Lordship Indra said again:

bhante bhagavā In truth, August-and-Sublimely-Meritorious, this divine being will be reborn in the form of a pig as a consequence of all the evil deeds that the August-and-Meritorious has just described to Lord Indra.

The Lord Buddha answered: mahārāj ekasmim jāto-atțhopapāno ${ }^{19}$ mahābhoggosamanabrāhmal ṇāti 
kuñacimanovirayo bikhanadetikhanosata parisati tasmä sukkham vobhavisanti In truth, Great King, this devaputta, in a previous existence, was born into a family of people who had considerable wealth. To this man religious people and ascetics came to ask for alms; in the same way, disinherited people, as many as they were, came to request some subsidy necessary for them. He did not give to any one. He locked himself in his house, closing the door, sitting indifferently, pretending not to see and hear. When the beggars left, [7-b] he opened his door again and came out of his house. This man was contemptuous of religious people and of ascetics. He said, "this monk does not recite the prayers harmoniously," or "this novice is unwilling to recite the prayers: all he does is walk around, begging everyone for money to spend.” The man hardly even had respectful words for the elderly monks, the ascetics, or the elders of his own family, all of them as many as they were. It is because of all these evil deeds that he must be reborn in this way.

somanasanakkhojātonihetukam Then the August Indra, king of kings, addressed the August One-who-has-Merits, the Master, bhante bhagavã:

In truth, O August-and-Sublimely-Meritorious One, this devaputta will be reborn in the form of a dog by the effect of the evil actions that the Master, the August-and-Meritorious One, has just described.

mahārāj so Ekasmiṇ kulesapanāyapakkhitāniddande buddho agāravodubhi so buddhagunam samghagunam napāsi. [8-a] Then the August declared:

"O Great King, it happened that when this devaputta was born in a family, he was shameless: he quarreled with the religious, novices and ascetics, as many as they were, as well as with scholars, doctors, masters of science, experts, with his own mother, with his father, and with his elders. He had no shame. He only knew how to insult, using profanity. He didn't recognize the virtues of good people in the slightest. It is because of these evil deeds that he must be reborn in the form of a mad dog.

sopatinapa rojatokidānam gahetukam bhante The August Indra, king of kings, replied to the August One-who-has-Merits: 
bhante-bhagavā Will this devaputta be reborn in the form of a deaf man because of the evil deeds which the Master has just spoken of?

Then the August One-who-has-Merits, He who taught the sublime Law said: mahārāja Ekasmiṇjātosama [8 b] yeridakkhiparisojātto añnasatthāñāna-sampanno dhammasutvā dulidukkha parisothānamganañca Ekamantam nisidi O Great King, regarding this devaputta, when he was born in Jambudvipa, in the world of men, it happened one day that another person, with a pure heart full of faith, undertook to invite a monk to preach the Great Law. This devaputta joined the others to listen to the sermon, but he could not concentrate on the teaching of the Law. All he did was talk about his gardens, his rice fields, and his hagglings when he was buying and selling. He spoke loudly to the people who were next to him, causing them to lose attention so that they could no longer listen to the teaching of the Sublime Law. This is the reason why this devaputta will be reborn in the form of a deaf and mute person, as a consequence of these evil deeds.

Then Indra, the king of kings, replied:

[9-a] bhante bhagavā Truly, O August-and-Sublimely-Meritorious One, why will this devaputta be reborn in the form of a blind man in his mother's womb? Tell us, O Augustus-and-Meritorious One, so that we know.

Then, the August-and-Meritorious One answered thus:

mahārāja pubbejāto samanabrāhmaṇakhantā disvā paramukhākatvāa aolokiyamānogaheva parițtho asīditvā tunhī ahosi O Great King, this devaputta, in a previous life, was born in the form of a man. This man saw a priest who came to make the morning quest for food, asking for areca and betel, and for the necessities of the four kinds. ${ }^{20}$ This man could see the priest in front of his house, but he feigned being a person who does not see and does not hear. He did not inquire [about what the priest wanted], he closed his eyes so as not to see him. He didn't say a word to him. It is because of this demeritory act that he will be reborn [9-b] in the form of a blind man from his mother's womb. 
sakodevarājāmahantam gāthaha His Supreme Lordship Indra, king of kings, most powerful among all gods, listened to the words of the Buddha, the August-and-Meritorious-One, then he uttered words which were no longer related to rebirths and demerits of the devaputta, but meant to recite formulas to greet the Master:

yenattathā hetabhantekenaso Indati Uppatitassaayacakkbi bhante In truth, $\mathrm{O}$ August-and-Sublimely-Meritorious-One, ayenadhammena August-One, Possessor-of-the-Most-Sublime-Qualities, yenadhammena what teachings should this devaputta follow so that he finds refuge? What should he do so that he remain permanently, in a stable way, in this precious paradise? We invoke your sublime august teaching for us to hear. We will listen and place this teaching on the top of our heads [10-a] as a refuge."

atthabhagavāmukhāgāmbhilamvivivarițā gāthà mahārāja Then the BuddhaWho-is-the-Master, had in his heart a desire to reveal [this teaching] as bright as a crystal box, atthi Unhassavijayo and began to speak again. A smile spread over his august lips, bright red like woolen fabric. ${ }^{21}$ The August preached like this:

atthi Unhassavijayo dhammoloke anuttaro sabbasat 'bitattāyatam tvam $\mathrm{O}$ Great King, greater than all the gods, as great as they may be, deign to listen to the Sublime August Law, the name of which is Unhissavijjaya, superior and precious above all, to which no other can be equaled. devaputtetvam This law is useful to all living things.

devaputte $\mathrm{O}$ devaputta, tvam Concentrate your attention. I, the Tathāgata, will recite the August Law [10-b] entitled Unhissavijjaya. Let it enter with respect through the door of your heart up to your memory with the greatest accuracy.

parivijjo räjadande amanussaginämake byagghenäge visebhüte akälamaranena ca sabbasmāmaranamuto thapetvā kälamarataṃtasseva änubhävena hontudevo ca sukkhi sadā $\mathrm{O}$ devaputta, this law is able to defeat all frightening enemies, as many as they may be in this world. Even more, at the time of the disintegration of the five aggregates groups, ${ }^{22}$ at the end of life, when the fright of ghosts and of the wickedness of spirits of the dead is born; when the fright of the dying comes; when one is afraid of perishing in fire; when one is afraid of being killed 
by aquatic spirits; when one is afraid of tigers, of bears, of wild men; when one is afraid of being trampled by elephants, afraid of being bitten by horses, of being gored by buffaloes, afraid of being bitten by dogs, afraid of being devoured by crocodiles; [and when one is] afraid of all kinds of spells that are cast so that one dies before reaching middle age, then the Sublime August Law entitled [11-a] Unhissavijjaya is able to resuscitate the life of men and women, as many as they are. It is capable of snatching them from all the vehicles of death, unless one has reached the term of his age, because then this law can do nothing against what is inevitable.

By the power of the Law which has for a name Unbissavijjaya, O devaputta, then thou will know a long age that will last, calm and pleasant, and happy, peaceful, free from pain, remaining in this paradise until the end of my teachings, the teachings of the Tathāgata, until the time of the teachings of August Si-Āry Metrīy. ${ }^{23}$ Then, O devaputta, thou will be reborn in the world of human beings likkhitam püjam dhāraṇam vācanam garum paresam desanam sutvā tassa àyu pavattati where you will enjoy a very long life.

Men, whoever you are, who have a pure heart, full of faith, may you inscribe [11-b] a copy of this text, may you keep it in memory, may you employ someone to make copies of it, may you keep a copy of this text with devotion, in order to learn it by pronouncing it repeatedly. May you invite monks to recite these fomulas in order to hear them, and if then you offer candles, incense sticks, garlands of Jasmine flowers as a sign of fearful respect. $\mathrm{O}$ folk, as many as you are, you will enjoy a long, peaceful life in happiness and fulfillment, as I, the Tathāgata, have just taught to you.

sakkatvā buddharattanam Aosutham Uttamam varam hidam devamanussānam buddha tejjena sotthinā nassantupadavā sabbe dukkkā vūpassamentu $\mathrm{O}$ Great king, this August Law is entitled Unbissavijjaya. If a person, being a man or a woman, recalls it with respect and fear, sakkatva buddharattanam if this person considers the Buddha, who is the sublime Jewel, ${ }^{24}$ as being his refuge, Aosutham as being his sublime remedy, Uttamam varam more powerful than [12-a] all medicines, considers him to be the August One-Who-is-the-Master, who is the August Refuge, bitam who is effective devamanussānam for gods, men and for living beings, as many as they are, sotthinā may luck hontu rest on him.

buddhatejjena May, by the magnificent power of the virtues of the BuddhaWho-is-the-Master, sabbe Upaddavā all fears vinassanti be destroyed and 
disappear. May $d u k k b \bar{a}$ the pains, as many as they are, vüpassamentu be destroyed and annihilated, tesam devamanussannam. This is worthy for gods and human beings, thanks to all the Virtues of the Buddha.

"sakkatvā dhammarattanam aosutham uttamam varam parilävüpassamannam dhammatejjena sotthinā nassantupaddavā sabbebhayà vüpassamentu te. yo puggalo If a person, whoever this person may be, sakkatvō regards with respect and fear, dhammaratanam the sublime Jewel of the supermundane laws, ${ }^{25}$ which derive from the August Law which is the Rule, which is a remedy, an august supremely excellent Uttamam medicine, [12-b] sublime varam beyond all medicines, paril $\bar{a} v \bar{u}^{26}$ of great efficiency devamanussänam for the gods, for men and for all living beings, as many as they are, hontu dhammatejjenasabbe Uppadavävinasantihontu possessing, dhammatejjena thanks to the power of the virtues of the August Law which is our Rule, sabbe Uppadav $\bar{a}^{-27}$ the frights of all kinds vinasanti will be destroyed sabbe bhayā vüpassamentuesam devamanussānam and driven out. Frights, sabbe bhayā, as many as they are, whatever they may be, vüpassamentu will be cast out. tesam devamanussānam This is true for all men and all living beings as much as they are.

"yo puggalo A person, whoever he is, sakkatva who regards with respect and fear samgharattanam the Jewel of the august Community, which is our sublime refuge, [13-a] Aosutham which is the sublime remedy, Uttamam supremely excellent, superior to remedies of all kinds, äbuneyyam worthy of receiving the offerings of gods and men, as many as they are, pähuneyyam as well as all the offerings which are brought to him, sotthina, may this person receive happiness sabbe Uppadava $\bar{a}$ thanks to the power of the virtues of the Community.

All frights, ${ }^{28}$ as many as they are, of all kinds, vinassanti, will be destroyed and disappear. sabberogā All diseases, as many as they are, vüpassamentu, will be driven out and healed. This is true tesam devamanussänam for gods, for men and all living beings, as many as they are.

yopuggalo If someone has a disease, and wants it to go away, that person must do the following: he must take a quantity of unhusked rice equal in weight to that of his body and roll a candle equal in height to his own [from the floor] to the top of his head, [13-b] then he must roll another candle the length of which is equal to the height from his shoulder to his hips, then make as many candles as the number of years of his age, each equal to the length of the span from thumb to the tip of the middle finger. He must prepare scented oil, lamps, candles, incense sticks, Jasmine flower garlands, then take the paddy 
whose weight is equal to his own, and shape it on the floor into a human figure. He must take a piece of white cotton veil and wrap it around his "shape of life," then he must invite venerable monks to come and recite the complete formula sakkatvā... one hundred and eight times. After having made all these rituals of offerings, this person should invite the monks to recite the text Unhissavijjaya. This person should focus his attention on the Law called Unbissavijjaya. Thanks to the "benefits" gained from listening to it, that person will live a long, peaceful and happy life, and will experience nothing but happiness.

Then this person should releases two-legged puñatejjena or four-legged animals. Thanks to all the merits that this person will have acquired in doing so, he [or she] will be free from the fears of death.

punatejjena Thank to the power of the merits of this August Law, which is a sublime remedy, this person will break with the fatal diseases [14-a] mantito of his body, so that they will fade and disappear, and that he will obtain happiness.

If a person, being a man or a woman, is full of wisdom, and if he [or she] seeks peaceful happiness, [he or she] must accomplish the paths and fruits useful to obtain the treasures of the three kinds- the earthly treasures, the heavenly treasures, the treasures of nibbanna-which are the places of the perfection of happiness and peace. May that person perform [these ritual] regularly, never omitting an occasion dana phalena in order to obtain the fruits of the gifts.

yo puggalo A person who makes offerings with "the rice of life" obtains a long life, is endowed with a strong body, a bright complexion, and constant luck, thanks to the fact that he will have heard the Law entitled Un hissavijjaya."

sako tenasiddhi bhagavato dhammam sutvā mane buddhantarakapañovasatilabhatim tile sako Indra, king of kings, the devaputta Supatitthita and the deities, as many as they were, [14-b] thus heard the the August Buddha-Who-is-the-Master preaching himself the August Law entitled Unhissavijjaya.

The devaputta Supatițhita then continued unabated until the end of the religion of the Buddha, who is our Supreme King, until the advent of the religion of the Bodhisatta Si-ametrey, who is the Master, all this thanks to the fruits of the merits of the August One-Who-is-the-Master, of the August Law, which is our Rule, as well as thanks to the morality of the gift which has helped him.

Uppaddava Concerning the frights of the eighteen kinds, ${ }^{29}$ they are destroyed and annihilated. yo puggalo A person who wants to have luck for 
himself, who wants to be able to overcome all his enemies, and to live long, may he proceed according to the prescribed ways taught by the Buddha-whois-the-Master.

desanāvasāne tu sotäpatiphalädinipāpanisum. Uṇhassavijivo Thus ended the preaching by the Buddha-Who-is-the-Master [15-a] entitled Unhissavijjaya. Indra, the king of kings, greater than all, the devaputta Supatitthita, and all the gods, as many as they were, having heard the Teaching of the August BuddhaWho-is-the-Master, had their hearts full of joy and faith, full of happiness and complete peace, following the August Buddha-Who-is-the-Master. Some, having heard it, reached the degree of Those-Who-Entered-the-Stream; ${ }^{30}$ some, having heard it reached the degree of Those-Who-Will-Return-OnlyOnce, ${ }^{31}$ or the degree of Those-Who-Will-Not-Return, ${ }^{32}$ or even the degree of Deserving, ${ }^{33}$ thanks to the merits and the fruitions acquired by each of them.

atthi unhassavijayo nittthito Thus we pronounce the formulas of the Unhissavijjaya, which is recompense for the adepts and the faithful, men and women. nitthitā The text is complete in all its parts are here. 


\section{Annex: Critical edition of the Khmer text}

[1-a] namotassa bhagavato arahatto sammāsambuddhassa ${ }^{34}$. ekasmim kira samaye satthä devatimnisabhavane viharanto pāritachattakamūle mahipandalakamūlè ${ }^{35}$ sisane nisìdi dassasa/ hassalokadhātu hisanipatitvā sabbedevā namahāmayādevā puttassapamukhā abhidhammasanganī adhika sattakaraṇam abhidhammakathesi. bho sādhuvo/ haiy sādhu sappuras' phan dāṃn ${ }^{\circ}$ hlāyöy ${ }^{\circ}$ kira tục yön pān 2 mak mān kāl sūmaiy thñai muoy noḥ satthā rī brạ̣ ța jā grūr visès nai yön dāṃn ${ }^{\circ}$ hlāy ${ }^{036}$. sojano devaputo noḥ/ gị devatā nau mahā jan’ phañ dāṃn ${ }^{\circ}$ hlāy kālnoh brạ ang gan’ nau löy ${ }^{037}$ braḥ ańg stec hoḥ ḷön dau gañ’ nau thān trai trịn stec ka cūl brạ̣ vassār brạ̣ an̉g saṃrā”n lör thm”ar sīlār ${ }^{38} /$ pād $^{\circ}$ jā dib āsnā saṃmtec brạ̣ indrār-dhirāj mān knun manda'l' briksā parijāti ${ }^{39}$ gịi ṭ̣om raluos ph-un tạ mān briksār kraham līön pịtūc phkār caṃmpār höy tạ mān kuṃboḥ 50 yojn e pravèn/

[1-b] cammmñā”y 60 yoj e thmar sīlāpād noḥ dan' pịṭuc saṃḹ ger thbec 1 thnai 7 țan kālnā pö braḥ indrādhirāj stec nin gan̉' lör kāl e nā höy thmar noḥ dan' cuh smör can̉keḥ brạ̣ ang noḥ hon. kālnā/ pö brạ̣ ang țoḥ krok lön ceñ $\bar{R}$ thma”r noḥ beñ țūc tạ țel viñ hoń . tadā aița kālnoḥ braḥ buddha ang tạ jā ammmcas thlai visès nai yön braḥ ang gan’'/ lör thmar dib āsnā saṃtec braḥ indrār-dhirāj pragen $^{40}$ țūcnoḥ höy ${ }^{\circ}$ brạ̣ ang tạ jā aṃmcāḥ trai bhab' dāṃn ${ }^{\circ}$ pìy $^{\circ}$ brạ̣ ang saṃmṭèn brạ̣ dhaṛm visès desnā gambīr brạ̣ abhidhamm dāṃn ${ }^{\circ}$ 7/ gambīr brạ̣ sañganīr ${ }^{41}$ jā tọm rīen dau țal' gambīr brạ̣ mahāpaț̣hān jā pań-as' jā santāp' as' devatā phan dāṃn ${ }^{\circ}$ hlāy ${ }^{\circ}$ mān nān mahāmāyā tạ jā buddhamātāân nau ind'/ braṃm jā pradhān brạ̣ añg desnār pān pī khèr gmān hau agg sūr saṃmlen̉ bīroḥ chān krān kra-uvv jrauv jrạ̣ hūr appamā” pītūc dik cụ̣ mak bī lö ākās ${ }^{43}$ noḥ hon. tadā e kodeval

[2-a] putto sapatitṭhitānāma abosi ${ }^{44}$ tadā aiṭa kālnoḥ mān devaputt 1 jhmoh hau supatiț̣hita devaput ka pān cūl dau köt nau suor-gār trai trịns țūcnoḥ höy ka mān pun pān soy sammmatti/ prasör lör bhīmān kuṃboḥ 15 yojn mān srīy debb-kañā"r dāmnn ${ }^{\circ}$ hlāy ${ }^{\circ} 1$ band' jā parivā" cāmmm pammrör jā saṃmrā"p' knun bhīmān prasād noḥ en̉ hon̉ mān srī dāṃn hlāy leñ/ bhleñ sèp saṃm-praguṃ țūr-țandrīy ${ }^{45}$ dāṃn $^{\circ}$ hlāy ${ }^{\circ}$ dāṃñ 5 jumbūk paṃmrör devaputt noh en hon e $e^{46}$ devaputt noh nau sabb thñai ka sūbhābb bum țin āyūs khluon ka nin cayutt/ cuḥ cāk ambīì suor devalok noḥ löy . tadà e ko ākāssaparitanāmadevaputto $\overline{\mathrm{R}}^{47}$ 
kālnoḥ as' devaput nau devațā ka tịn țèl nau jā prakrațīy noḥ/ ka dau. canava ākāssaparini nau nār knun mand'al' höy ${ }^{\circ}$ ka gungit rumbịn bịcāraṇā möl āyūs devaputt phan noḥ ka ṭin thā supatiț̣hita devaput neḥ nin as'āyūs höyº

[2-b] as' devaput phan dāṃn ${ }^{\circ}$ hlāy ${ }^{\circ}$ ka mak bīgroh thā țucneh ${ }^{48}$. devaputtabbümari dassasattame desenà toputtomanahantadukkham anubhavanto döb devațā nāṃm ${ }^{\circ}$ gnā dau dūl saṃmtec aṃmrin indrādhirāj brạ̣ ang țin/ san̉khār āyūs supatițțhitadevaputt nin as' āyūs döb saṃmtec indrādhirāj mān brạ̣ pandūl prāp' mak devaput dāṃn ${ }^{\circ}$ noḥ thā ao as' devațā phan dāṃñ hlāyöy / anak min țin de hạ̣ nūr nè supatițthita ang neḥ nau tè 7 thniai diet ${ }^{49} \mathrm{ka}$ gāt' nin cayut cuḥ cāk aṃbì thān suo neḥ höy ${ }^{\circ}$ ka gāât' nin pān cụ̣ dau köt ${ }^{50}$ nau nār/ avacī nărak' dal' dukkh vedanā ka crön jāti pān muoy band' chnāṃ narak' noḥ hon kālnār pö ruoj aṃīi naruk lọn mak köt jā satv' tiracchān phan dāṃñ hlāy 7 juṃbūk/ crön jānd' noḥ hon̉ anak noḥ nin dau köt jā antök jā jrūk khlèn gūk tmāt k-èk chkèr chmā ruoc höy ${ }^{\circ}$ ka mak köt jā manuss trajiek thla” n̉ bhnèk khvāk aṃbīy ${ }^{\circ}$ knun̉ boḥ mtāy ceñ mak/

[3-a] jā mūy bānd' jāt hon luḥ kālnār devaput noḥ prāp țūcnoḥ höy ${ }^{\circ}$ atarapāyititi sotassavacanam sutvā kapanohadayosovaputto. döb supatițthitadevaput noḥ ka pān/ प̣ saṃtec aṃmrin indrādhirāj mān brạ̣ pandūl prāp' thā saṃkhār àtmār ${ }^{52}$ sūrabhābb āyūs khluon buṃ dīen țūcnoḥ höy ka mān citt noḥ bhit bhaiy ${ }^{\circ}$ hāradaiy ${ }^{\circ}$ noḥ rundhat'/ andās' andèn dau viñ dau mak sn̉uot sn̉ap' sub sau tpid mān mundil knun̉ khluon ${ }^{53}$ țūcnoḥ hon. tadā kime evarūppāna uppaț̣havobhavisanti. aița kālnoḥ su/ patițthita devaput bhit bhaiy ${ }^{\circ}$ sandhik citt ${ }^{54}$ țūcnoḥ höy ${ }^{\circ}$ ka git bīcāranā thā ao añöy dhvö mtec kar nin pān ruoj cāk ceñ aṃbīy akusal' mak phtal' phtec āyūs/ ang añ țūcneh . ao aniccārūppöy ${ }^{\circ}$ nin rak avīy jā buṃnāk dỉbịn bumnin nọ̣ gmān löy ${ }^{055}$. pubbanimittam gịi pubbanimit dāṃñ hlāy ka köt mān nau ang añ $\tilde{n}^{56}$ ṭucnoḥ mūyo gịi saṃbat'/

[3-b] sliek nau spèk ${ }^{57}$ ka sin āp' sauma"n phkār añ phan̉ ka sin svit sn̉uot pañ' sīet rāksmī nau ñös khluon prān añ ka hūr ceñ aṃbī khluon ${ }^{58}$ añöy an̉g prān añ ka sau ma”’ ākrak'/ āsnār țạ̣mnek tẹk añ ka köt ceñ jā rapịn rịn rūs phlèk lös lan’ ban' pramā”n thā ao aniccā rūppöy köt mak jā devaputt devațār höy ka pān/ cayutt srut cuḥ cāk ceñ aṃbī thān bhimān ṭa mān luṃ-ar nọ̣ phsen aor srīy ${ }^{\circ}$ deb aksar pava”r kañār snèhār saṃmleñ añöy sam nin brāt'/ prās nīrās nin gnā 
dau hon ka hètu tè akusal mak phtal' phtec ang añ neḥ. attanopubbanimittam disvā bhavisanti sariratosedopañcati ${ }^{59}$ sariraducuti/ saṃdevaputtedhammam. pubbanimit dāṃn ${ }^{\circ}$ hlāy yöy ${ }^{00} 5$ jumbūk neh prākaț̣h' knun̉ khluon añ ka sin köt mān mak aṃbī mun noḥ hoń doḥ devaput devațār dāṃn ${ }^{\circ}$ hlāy pö cayutt cuh/

[4-a] cāk ambīi suor höy ${ }^{\circ}$ ka sin tè țūcnoh en hon döb devaput git tụcnoḥ höy ka lök kuṃpan’ añjaliy ${ }^{\circ}$ praṇum tạ̄k' lö sirisīy ${ }^{\circ}$ krāp' thvāy ${ }^{\circ}$ pañgạ̣ saṃtec indrārdhirāj ${ }^{61} \mathrm{ka} /$ anguy tọy nau dī luṃnau ātmā en̉ hon höy dūl brạ idrār-dhirāj thā tụ̂cneh . bho devarāja tvam mesāmi $i^{62}$ patisaranamkarohi abaṃmedivase cutol aviciniraye ${ }^{63}$ nibbato tatha banivassasahassä ${ }^{-64}$ na abantam dukkham anubhavisāmi. bho devarāj thā pabit saṃtec aṃrin indrādhirāj nanātṭh jā ị̂sūr kuṃ/ būl jā aṃmcās' as' devațār phan̉ dāṃn hlāy yöy ${ }^{05}$ tvaṃ tathā mahārāj pabit mahārāj țā jā dībịn naiy ${ }^{\circ}$ khñummöy ${ }^{066}$ aṃham rī añ khñum aṃbī nẹ̣ dau nau tèr/ 7 thniai der nin cayutt cuh ccāk aṃbīy thān bhīmān devalok suor höy ${ }^{\circ}$ ka nin dau köt nau nā avacī narak' soy ${ }^{\circ}$ dukkh vedanār yūr lañ' muoy bānd' chnāṃ narak' țūc braḥ ang prāp' khñum/

[4-b] noḥ hon höy ${ }^{\circ}$ ka sūtr nau pad brạ̣ gāththā țūcneḥ. natthi me saparāyanodevovattanāseț̣̣̣o devarājā sapatitvaṃ hiseț̣holokasmiṃnāhaṃ devohiddhiko ${ }^{67}$ tilokemangalase/ ț̣ho lokapāpampāvāhano ${ }^{68}$. thā pabit brạ̣ añg hon jā visès naiy ${ }^{\circ}$ devatār manuss satv' phan dāṃn ${ }^{\circ}$ hlāy ${ }^{\circ}$ bum mān anak e ṇā 1 nin smör nin amcāḥ noḥ/ gmān löy braḥ ang aṃmcās' jā ddhạ̣ mān puṇ saṃmbhār braḥ pāramī ${ }^{-69}$ riddhī ānubhābb jā mañgal' prasör buṃnākkh' naiy khñum hon. sutvā sakodevarāj. döbb/ saṃtec aṃmrin indrār-dhirāj pān ḷ bāk nai supatiț̣hitadevaput dūl prāp' thā țūcnoḥ höy ${ }^{\circ}$ ka sūtr nau pad brạ̣ gāthā țūcneh. aham seț̣holok/ smim nāhamdevo mahiddhikotiloke mańgalaseț̣ho lokapāpampavāhano ${ }^{70}$. döb saṃmtec brạ̣ indrār-dhirāj mān brạ̣ pandūl dau nin supatiț̣hitadevaput noh thā/

[5-a] ahạ̣ rīy añ khñum neh nin jā dhaṃm ${ }^{71}$ prasör lös lèn trai bhab’ dāṃn pīy $^{\circ}$ neḥ ka der añ nin mān prājñār mān riddhī āj juṃrāḥ as' pāpakamm anak dāṃn trai bhabb' dāṃn ${ }^{\circ}$ pìy ${ }^{\circ}$ nẹ̣ bum pān löy hon./ lokanāț̣haṃ thapetvā aññạ̣ passāmimaṅgalam sabhāraṃ nikonātṭho lokahitā sano anuthasisampadāā anuttaro devanañca hitatthāyadesanā. thā haiy / devaputöy añ ruṃbịn yal' trai

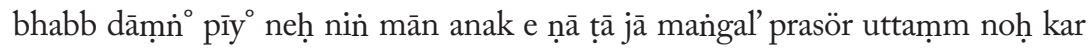


gmān löy mān puntèr braḥ ța mān pun jā aṃ-/ mcās' braḥ ang pān trās prājñār sārabejațānāṇ jā braḥ buddh prākaț̣̂h' krai lèn lös lok phan dāṃñ hlāy ${ }^{073}$ brah ang jā buṃnāk' trai bhabb' dāṃñ pīy neḥ/ sin pān hon brạ̣ ang tèn nin rak aoy ${ }^{\circ}$ prayojan jā bumnnāk' nai satv phan dāṃn hlāy nau manuss devațār ind braṃhm noḥ sin pān hon. so bhagavā. braḥ/

[5-b] buddh jā aṃmcās ${ }^{74}$ noḥ mān rāksmīr cabbăṇnarāṃnnsī ța mān 1-ar lös labb' lok phan dāṃn ${ }^{\circ}$ hlāy nin yak anak e ṇā mak phdim nin brạ̣ an̉g buṃ pān löy hon. nātho ka jā dībịn höy / āj kuṃcāt' as' pāp bīer buṃnār verākamm phan dāṃñ hlāy nau knun lokkīy neḥ sin pān hon̉ ilūvneḥ brạ̣ ang mak gun desnār nau nār thān yönn nẹ̣ hoǹ/ tasmā pö țūcneh ka yön dāṃñ bīr guor cūl dau buṃnāk' saṃmnāk' bīn braḥ buddh ța jā aṃmcās' hoń. so deva putto rī devaputt ${ }^{75}$ Ḷ bāk braḥ indrār-dhirāj/ höy mān citt trek-ar sādar krai bek ṇās' höy ${ }^{\circ}$ ka mān tạiy kān' nī dau nau dīen dhūp gandhamāāār phkā bhñ̄îr ${ }^{76}$ jār țöm ka dau jā muoy nin braḥ indrār-dhi-/ rāj. tasmāno ka cūl dau saṃnākkh' braḥ ța mān puṇ hon. yenabhagavā rī braḥ buddh ța jā aṃmcāḥ brạ̣ angañ’ trañ' sṭhān e ṇā $\overline{7}^{77}$ braḥ indrār-dhirāj ka cūl dau tran̉ dī noḥ/

[6-a] hon. lụ̣ cūl dau țal' höy ${ }^{\circ}$ ka lök kumpan añjalīy țāk' lö sirasār krāp’ thvāyo pañgamm pūjā ${ }^{78}$ nau dīen dhūp gandhamālā phkār bhñīr jā tọm höy angguy $^{79}$ țoy ${ }^{\circ}$ nau/ dī samguor nin ātmā hon̉. tadā aițar kālnoḥ saṃṭec indrādhirāj ka krāp’ dūl braḥ ṭa mān pun thā țūcneḥ. bhante bhagavā pabit braḥ țar/ mān pun jā aṃmcās' visès khñummmöy ${ }^{\circ}$ tpid devaput noḥ nām jhmoḥ supatiț̣hita kuṃnaț̣̂h' khān tè 7 thñai dīet ka nin căyut cuh cāk aṃbī thān suor ka dhlāk' dau/ avicī narak' soy duk vedanār țoy ${ }^{\circ}$ nau kammavipāk akusal țūc-mtec ka sūmdān brạ̣ ang yak prāiñār dib visès noḥ mak saṃțèn prāp' naiy yöñ khñum phan̉ hon. bhagavā rīy brạ̣ ța mān pun jā aṃmcās' brạ̣ ang nin̉ țọ̣ visajjanā saṃtecc braḥ indrār-dhirāj aoy pān tịn höy ka brạ añg desnār thā. sobbajāto ekasmim ki-/

[6-b] lesu jethako ahosi tasmābijaṃ. döb braḥ anig mān braḥ pandūl thā. mahārāj pabit mahārājöy ${ }^{\circ}$ rìy devaput neh kāl jāt mun löy devaput neḥ pān dauv ${ }^{80}$ köt knun trakūl pramāñ jā dhaṃm krai lèn brān phan dāṃn hlāy tèn nin saṃmlāp' satv' yak mak jiñcim jīvit khluon ${ }^{81}$ bum țèl țec löy ${ }^{0}$ ka hètu tèr/ aṃbör țūcnoḥ döb köt jā satv' tmā”t jā an'-ṭök jā jrūk jā chkèr noḥ hon kālnoḥ brạ̣ indrārdhirāj thvāy ${ }^{\circ}$ pangaṃm dūl thā bhante bhagavā pabit/ braḥ ța mān punöy ${ }^{\circ}$ 
deveput añg neḥ nin pān dau köt jā satv phan tọo nau kammavipāk mtec miñ. somahārājapubbejāto antamakkhipiyo/ tegahetvā ${ }^{-82}$ tasmā pubbojātobhavissatti. haiy ${ }^{\circ}$ mahārājöy ${ }^{\circ}$ devaput nẹ̣ kāl gāt' aṃbī jāt mun miñ noḥ gāt ${ }^{\prime 83}$ tèn nin yak ban̉ satv' mak sṅo"r sīr paṃmrās' aṃbīyo saṃ/-

[7-a] puk mevār hèt noḥ pān jā dau köt jā satv' tiracchān ${ }^{84}$ hon döb braḥ indrādhirāj thā bhante bhagavā pabit brạ̣ ța mān pun prasöröy ${ }^{\circ}$ rīy devaput neh nin pān dau köt jā jrūk noḥ/ hètu kammavipāk aviy döb ța mān pun brạ̣ ang saṃtèn thlèn prāp' braḥ indrār-dhirāj thā. mahārāj ekasmị̣ jāto-aț̣hopapāno ${ }^{85}$ mahābhoggosamaṇabrāhma/ ṇāti kuñacimanovirayo bikhanadetikhanosata parisati tasmā sukkhạ̣ vobhavisanti ${ }^{86}$. tha ${ }^{-87}$ pabit mahārājöy devaput nẹ ạ̣bī kāl jāt mun löy ${ }^{\circ}$ pān/ dau köt nau trakūl anak ṭa mān drāp' saṃmpatti crön purass noḥ anak brạ̣ saṃgh ${ }^{88}$ samaṇabrāhm smūm yācak' anak kuṃsad dugat' phan dāṃn ${ }^{\circ}$ hlāy ${ }^{\circ}$ mak sūm dān ktīy/ tpid tè khluon mān prayojan nau drāb' phan noḥ ka bum aoy jā dān löy cōl dau knun phdạ̣ nai khluon puon rāṃñ dvār anguy nau prañöy dhvö buṃ ṭin buṃ yal' luḥ tè smūm yācakkh' tör huos/

[7-b] dau ${ }^{89}$ höy döb pök dvār ceñ mak aṃbī knuñ phdạ̣ purass noḥ tèn māgg' ṅāy ${ }^{\circ}$ teh ṭiel braḥ bhikkhu sāmmaṇer ${ }^{90}$ thā ang neh sūt dhaṛm min bīros thā sāmmaṇer neḥ khjil sūt ṇās' tèr rak/ țör sūm ${ }^{91}$ sārabör ger chīy nin mān bāk gorab' praṇipatti bhikkhu sāmmaṇer cās' dum srạ̣m brāhm trakūl rīem cpan phan dāṃn ${ }^{\circ}$ hlāy $^{\circ}$ aoy jā l-ar țal' tic löy ${ }^{\circ}$ hètu/ tèr kammavipāk noḥ en ka pān dau köt jār jrūk ṭūcnoḥ hon. somanasaṇakkhojātonihetukaṃ ${ }^{92}$. döb brạ indrār-dhirāj dūl țantin brạ̣ țā mān pun jā/ aṃmcās' thā. bhante bhagavā pabit brạ̣ tạ mān pun prasöröy ${ }^{\circ}$ rī devaput noḥ nin pān dau köt jā chkèr noḥ tö tọo ${ }^{\circ}$ kammavipāk avīy țūc-mtec aṃmcās ${ }^{93}$ döb braḥ/ țā mān pun brạ̣ an̉g nin thlèn saṃtèn nau kammavipāk țūcnoh thār. mahārāj so ekasmị̣ kulesapanāyapakkhitāniddande buddho agāravodubhi so buddhaguṇaṃ saṃghaguṇaṃ napāsi ${ }^{94} /$

[8-a] döb braḥ ang mān pandū1 ${ }^{95}$ thā mahārājöy ${ }^{\circ}$ kālnoḥ devaput neh pān dau köt nau trakūl muoy anlör ka purass noh bum kot krèn tèn jer anak brạ sañs ${ }^{96}$ bikkhuthèr sāmmaṇer nau/ samaṇabrāhm phań dāṃn hlāy nau anak prāj rājamuṇdit brị̣hụhācār grūr pād-dhyāy mtāy uvbuk trakūl rīem cpań phan buṃ kot krèn mān tèr tmāḥ ${ }^{97}$ tẹ̣ țiel/ nau bāk ākrak' buṃ țin guṇ lok ṭa mān gụ tạl tic löy hètu tè kammavipāk noḥ en pān dauv köt jā chkèr chkuot no 
hon. sopatinapa/ rojatokidānaṃ gahetukaṃ bhante ti. braḥ indrār-dhirāj ka dūl brạ ța mān pun viñ ${ }^{98}$ diet thā. bhante bhagavā. pabit brạ ța mān pun-nöy devaput noḥ/ pān dau köt jā manuss trajīek thlañ' noḥ tör hètu tèr aṃbör kamm tūc-mtec ammmcās'. döb braḥ ța mān pun saṃtẹn braḥ dhaṛm visès desnār thā. mahārāja ekasmim ${ }^{99}$ jātosama/

[8-b] yeridakkhiparisojātto aññasatthāñānasampanno dhammasutvā dulidukkha parisothānam $^{100}$ ganañca ekamantạ̣ nisīdi. nèr mahāāaj-jöy ${ }^{0}$ devaput neḥ ${ }^{101}$ kālnoḥ pān dau köt nau nār/ jummmbūr-dhvipp manussalok noḥ nau prakrațīy ${ }^{\circ}$ juop juon samăy muoy ${ }^{\circ}$ thñai noḥ anak țadaiy ger mān citt kāt' țạ̣̣̄a saddhār papuol gnā nīmant' braḥ sangh mak saṃțèn/ brạ̣ dhaṛm visès desnār e devaputt ka cūl dau ${ }^{102}$ stāp' nin ger ka purass devaput noḥ buṃ pān phgut phgañ' țamra"n citt stāp' braḥ dhaṛm visès desnā löy tèn anguy/ nīyāy ț̣öm aṃbīr caṃmkār ${ }^{103}$ srèr juoñ prèr lalak dandiñ höy ${ }^{\circ}$ srațīy aoy khlāṃn anak țadaiy ${ }^{\circ}$ nau dīep sin bhlāt' smāṭī nin țammran citt stāp' braḥ dhaṛm visès desnā/ noḥ bum pān löy hètu țūcnoḥ pān jā devaputt noḥ dau köt jā manuss trajīek thlañ' țoy ${ }^{\circ}$ nau kammavipāk $k^{104}$ noḥ hon döb brạ̣ idrār-dhirāj dūl țantin viñ dīet thā./

[9-a] bhante bhagavā pabit braḥ ța mān prasöröy ${ }^{0105} \bar{R}$ devaput neḥ dau köt jā manuss khvāk ${ }^{106}$ aṃbī knun boḥ mtāy ceñ mak noḥ tör hèt akusal ṭ̂̄c mtec ka cūl brạ añg saṃțèn thlèn aoy khñuṃ/ brạ̣ karuṇā ṭin phan hon döb brạ̣ ang mān pandūl desnā viñ dīet ${ }^{107}$ thā țūcneḥ. mahārāja pubbejāto samaṇabrāhmaṇakhantā ${ }^{108}$ disvā paramukhākatvā/ aolokiyamānogaheva pariț̣ho asīditvā tuṇhī ahosi ${ }^{109}$. hai mahārājöyo rī devaput neh nā kāl jāt mun köt jā manuss höy ${ }^{0}$ ka purass noh ${ }^{110} /$ ghöñ anak brạ sangh bhikkhu thèr sāmmaṇèr mak piṇdapāât nau slā mlūr nau paccay dāṃn ${ }^{\circ} 4$ juṃbūk ka purass noḥ luḥ tạl' mukh phdaḥ ātmā höy ${ }^{\circ}$ kar dhvör/ kantöy pranöy bum nāṃm bārrr-țamān khaṃm dhmec bhnèk dhvör jā min ghöñ höy ${ }^{0111}$ bum sraṭị țal' muoy mă”t' löy ${ }^{\circ}$ ka hèt tè aṃbör akusal țūcnoḥ döb mak köt jā manuss/

[9-b] bhnèk khvāk' aṃbī knun phdai mtāy ${ }^{\circ}$ luh tè ceñ mak noḥ hon̉. sakodevarājāmahantam gāthaha ${ }^{112}$. saṃṭec ${ }^{113}$ ammmrin indrādhirāj mān aṃnāc jā ammmcāḥ as' devațā phan dāṃñ hlāy / pān stāp' brạ̣ buddh-ṭikār brạ̣ ța mān pun höy ${ }^{\circ}$ ka mān braḥ pandūl srāy visajjanā aṃbī pubbajāat kuṃnöt pāpakamm ${ }^{114}$ nai devaput noḥ döb sūt nau pad brạ̣/ gāthār thvāy brạ̣ ța jā 
amcāḥ hon. yenattathā hetabhante ${ }^{115}$ kenaso indati uppatitassa ${ }^{116}$ ayacakkhi bhante. pabit braḥ ța mān pun prasöröy ${ }^{\circ}$ braḥ ang mān/ lakkhiṇā noḥ 1-ar prasör krai bek. yenadhammena tọ ${ }^{\circ}$ dhaṛm tūc mtec ka nin pān jā dỉbịn nai devaput nẹ̣ dhvö ${ }^{117}$ tūc metec ka devaput nin gan̉ nau thit/ ther yịn yūr khjāp' khjuon nau nār saṃmpatti suor bhimān noḥ ka sūm ārāddhanār brạ̣ dhaṛm visès desnār trañ' e ṇā jā santāp' yön khñum brạ̣ karuṇār ka nin trañ' trāp' tạk' lö sirasā/

[10-a] jā buṃnāk' dau hon. aț̣habhagavāmukhāā18 gāmbhilamvivaritvā gāthā mahārāja. kālnoḥ brạ̣ buddh ṭa jā aṃmcās' brạ̣ ang mān brạ̣ rāj hādaiyo nin cañ' srāy ${ }^{\circ}$ prakap kèv ${ }^{119}$ höy / samṭèn thlèn ḷon ța mān braḥ aos ñañim pa”raprim kraham 1-ar pītūc saṃbatth' ratn kambal brạ̣ ang kar desnā țūcneh ${ }^{120}$. atthi uṇhassavijayo/ dhammoloke anuttaro sabbasat' hitattāyatam tvam gaṇhāhidevate. thā hai mahārāj ța jā ddhaṃ lös as' devaṭār phañ dāṃn ${ }^{\circ}$ hlāy yöy ${ }^{\circ}$ ka cūl anak/ yak sottapasāda trañ ${ }^{\prime 121}$ trāp' stāp' brạ̣ dhaṛm visès desnār jhmoh hau uṇhassavijay țar jā uvțạmm ${ }^{122}$ thlār thlai prabaiy beky niñ rak avīy mak phdim aoy ${ }^{\circ}$ smör/ bum pān löy ${ }^{\circ}$ brah dhamm neh nin aoy ${ }^{\circ}$ prayoj $^{123}$ naiy ${ }^{\circ}$ satv phan dāṃn ${ }^{\circ}$ hlāy ${ }^{\circ}$ devaputte ${ }^{124}$ thā haiy ${ }^{\circ}$ devaputöy ${ }^{\circ}$ tvam ka cūl anak tāṃn 'omāṭ̄ stāp' hon tathāgat' nin yak nau brạ̣ dhaṛm/

[10-b] uṇhassavijjayya ${ }^{125} \mathrm{ka}$ cūl gorabbh' cāṃmº duk knun manodvār vicī citt $^{126}$ aoy ${ }^{\circ}$ khjāp' jāk' prākațth' hon. parivijjo rājadande amanussatināmake byagghenāge visebhūte akālamaraṇena/ ca sabbasma ${ }^{127}$ maranamuto thapetvā kālamaratạ̣tasseva ānubhāvena hontudevo ca sukkhī sadā. thā haiy ${ }^{\circ}$ devaputöy ${ }^{\circ}$ brạ̣ dhậm neh àj jhnạ̣ phlāñn' as' satrūv phan dāṃn buon̉ köt ${ }^{128}$ aiṭa lok neh nin ruṃlān pañcakhandh phtal' phtec vi cìvit ktī doḥ köt bhaiy aṃbī khmoc ktī pīsāc kuṃnāc nin slāp’/ ktī köt bhaiy aṃbī bhlön cheh dọ̣ köt bhai aṃbī khmoc knun dik nin slāp' ktī bhaiy aṃbī khlār dhaṃm khlār ghmum manuss brai ktîn ${ }^{129}$ bhaiy $^{\circ}$ aṃbī țamrīy ${ }^{\circ}$ brec seh khāṃm/ krapīy vāt' chkèr khāṃm krabör lep bhaiy aṃbī krittiyā ${ }^{\circ 130}$ ge dhvö nau sārabör dāṃñ as' dāṃn ${ }^{\circ}$ buon mak dhvör aoy slāp' buṃ dān' cās' buṃ dān' dummm tūcnoḥ noḥ braḥ dharm visès desnā jhmoḥ/

[11-a] hau uṇhassavijay noḥ āj pros yak jīvit nai puggal' pruḥ srīy ${ }^{\circ}$ phan dāṃn ${ }^{\circ}$ hlāy

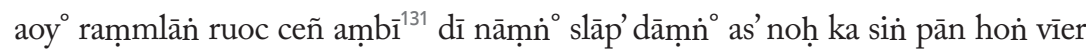
puntèr cās' duṃm saṃguor niñ/ āyūs saṃkhār dhaṛm sanma”'t' jīes buṃ pān 
löy hètu tọy nau ānubhābb pān braḥ dhaṛm ${ }^{132}$ neḥ jhmoḥ hau uṇhassavijayy ka devaput noḥ döb niñ/mān āyūs vèn yịin yūr thit ther sranuk ${ }^{133}$ sukh sappāy $^{134}$ khsèm khsān buṃ mān dukkh pān gañ' nau lör bhīmān ${ }^{135}$ noḥ pān hon̉ luḥ as' brạ̣ sā-/ snār añg añ țathāgat' neḥ nin pān țal' sāsnār braḥ si-āmetrī dāṃñ bī brạ̣ ang neh döb devaput noḥ pān cyut cụ̣ dau hon narū purass ${ }^{{ }^{136}}$ prụ̣ srī/ e ṇā nin mān āyūs vèn yị̣n yūr. likkhitạ̣ pūjam dhāraṇaṃ vācanaṃ garuṃ paresaṃ desanaṃ sutvā tassa āyu pavattati. narū parus' puggal' e ṇā mān citt ${ }^{137}$ țạ̣mlār saddhār pān sāì/

[11-b] sar-ser cār ktī pān raị̂k nik tạl' ktī pān juol anak tadai aoy saser cār ktī pān duk gorabb' praṇipatti ktī pān rīen dundeñ svādhyāy ktī pān nīmunt ${ }^{138}$ anak brạ̣ sangh desnār/ aoy stāp' ktī höy pūjā dīen dhūp phkār bhñīr gorabb' pranipatt kot krèn puggal' anak dāṃn ${ }^{\circ}$ hlāy no nạ ka nin mān āyuh vèn yị̣n yūr thit ther sukh ${ }^{139}$ suor stīy saṃriddhî ${ }^{-140}$ mangal' țūc kāl brạ̣ tathāgat' gañ' dhammā desnār mak neḥ hon. sakkatvā buddharattanaṃ aosuthaṃ uttamaṃ varaṃ hidạ̣ devamanussānam buddha/ tejjena sotthinā nassantupadavā sabbe dukkkā vūpassamentu te. thā haiy mahārājöy ${ }^{\circ}$ rì braḥ dhaṛm neḥ jhmoḥ ${ }^{141}$ uṇhassavijayy narū paras' puggal' pruḥ srīy e/ ṇā muoy pān gorabb' pranipatti koṭ krèn. sakkatvā buddharattanaṃ. gịi braḥ buddh ța jā țuoń kèv prasör tèn nin buṃnāk' aosuthaṃ ța jā thnāṃ dibb an̉g prasör uttamaṃ varaṃ ṭa lös lèn/

[12-a] thnāṃ dāṃñ hlāy braḥ ța jā aṃmcāḥ brạ̣ ang jā dībịn. hitạ̣ ṭa jā prayojan. devamanussānaṃ nai devața $\bar{a}^{142}$ manuss satv' phan dāṃn ${ }^{\circ}$ hlāy ${ }^{\circ}$ sotthinā gịi srī suostī hontu ka cūl mān/ buddhatejjena tọo ānubhābb tèjjạ̣ tpạ̣ guṇ braḥ buddh ța jā ammmcāḥ sabbe upaddavā rī bhaiy phan dāṃñ hlāy vinassanti ka aoy vinās pāt' pañ' dau hon̉./ dukkhā rī dukkh phañ ${ }^{143}$ dāṃn ${ }^{\circ}$ hlāy ${ }^{\circ}$ vūpassamentu ka cūl rummmnāp’ ruṃlut pāt' pañ' khcāt khcāy . tesaṃ devamanussānaṃ țal' devaṭā manuss phan țoy nau jumbūk noḥ hoń/ . sakkatvā dhammarattanaṃ aosutham uttamạ̣ varam parị̣̂avūpassamannam dhammatejjena sotthinā nassantupaddavā sabbebhayā vūpassamentu te. yo puggalo rī puggal' e/ ṇār muoy sakkatvā ka pān dhvör gorabb' kot krèn höy ${ }^{\circ}$ dhammaratanam nau țuon kèv prasör nau lokuttar ${ }^{144}$ gị̣ brạ̣ dhaṛm ṭa jā aṃmcās' aosuthaṃ gị̣ thnāṃ dib prasör braḥ an̉g uttamaṃ/

[12-b] tạ jā uvtammm bek ṇās' varam ṭa prasör lös lèn thnāṃ dāṃñ buon̉. parị̣̂avū ka jrau jrāss ${ }^{145}$ aoy köt prayojn devamanussānam țal' devațā manuss satv' 
phan dāṃn hlāyo ța jā sukh suor-stī/ hontu ka cūl mān dhammatejjena toy ${ }^{\circ}$ ānubhābb pun braḥ dhaṛm țar jā aṃmcās'. sabbe uppadavā rīy bhai dāṃn ${ }^{\circ}$ buon $^{146}$ vinasanti ka aoy vinās/ pāt' khcāt' khcāy ${ }^{\circ}$ pañ $^{147}$ ceñ dau hon. sabbe bhayā rī bhaiy ${ }^{\circ}$ dāṃn ${ }^{\circ}$ hlāy dāṃn ${ }^{\circ}$ buon. vūpassamentu ka aoy raṃmnāāp ${ }^{148}$ patt' pań' dau hon. tesaṃ devamanussānaṃ țal'/ devațār manuss satv' phan' dāṃn ${ }^{\circ}$ hlāy ${ }^{\circ}$ noḥ. sakkatvā saṃgharattanam aosuthạ̣ uttamam varam āhuṇeyyam pāhuṇeyyaṃ saṃghatejjena sotthinā nassantupadda/ vā sabberoggā vūpassamentu te. yo puggalo rī puggal e ṇā muoy sakkatvā ka pān gorabb' ${ }^{149}$ kot krèn saṃgharattanam nau tuon kèv ratn braḥ saṃngh prasör jā buṃnāk'/

[13-a] aosutham țā jā thnāṃ dib ang prasör uttamạ̣ țar uvtaṃm bek ṇās' varaṃ ka prasör lös lèn thnāṃ dāṃn ${ }^{\circ}$ buon āhuṇeyyam ka daduol ${ }^{150}$ yak grīön pūjā devatāa manuss satv' phañ/ dāṃn ${ }^{\circ}$ hlāy pāhuṇeyyam nau griön manuss phan dāṃn ${ }^{\circ}$ hlāy ${ }^{\circ 151}$ prațāp' cāmmm nāmmm ${ }^{\circ}$ yak mak ktī sotthinā tạ jā sukh srī suostîn ${ }^{-152}$ hontu ka cūl mān tèjjạ̣ ānubhābb' pun' braḥ sangh sabbe uppadavā rīy kāy ${ }^{0153}$ phan dāṃn ${ }^{\circ}$ hlāy ${ }^{\circ}$ dāṃn ${ }^{\circ}$ buon vinassanti ka aoy ${ }^{\circ}$ ralat' ralāy ${ }^{\circ}$ khcāt' khcāy ${ }^{\circ}$ pāt' dau sabberogā rī rog byā-/ dhi dāṃn hlāy dāṃn ${ }^{\circ}$ buoñ vūpassamentu ka aoy ${ }^{\circ}$ ralut' khcāt'154 pañ jā hon். tesạ̣ devamanussānaṃ țal' devațār manuss satv' phan dāṃn ${ }^{\circ}$ hlāy ${ }^{\circ}$ noh hoń. yo/ puggalo rīy puggal' e ṇā muoy köt byādhdhi höy ${ }^{\circ}$ nin aoy ralat' ralāy ${ }^{0155}$ noḥ thā țūcneh aoy puggal' noḥ yak an̉kar mak thlịn duṃm-ṅan’ smör khloun höy aoy luñ dīen pravèn kpāl/

[13-b] muoy ${ }^{\circ}$ dīen muoy aoy ${ }^{\circ}$ vās' pravèn aṃbī smār mak țal' can̉keh dīen muoy aoy vās' yak aṃmrām țaiy ${ }^{\circ}$ kantāl noḥ aoy grāp' āyuh aoy riep pren̉ pradibb dīen dhūp gandhamālār phkār bhñīr höy aoy\% yak an̉kar dummmnan' smör khluon mak dhvör jā rūp manus höy ${ }^{\circ}$ yak saṃbat' sar grap rūp ang jivit ${ }^{156}$ noh ruoc aoy nīmunt anak brạ̣ saṅgh mak sūtr braḥ dharm sakkatvā pān ${ }^{157} 1$ ray / 8 cap' höy ${ }^{\circ}$ pūjā pantār kār dāṃn ${ }^{\circ}$ noḥ ruoc höy ${ }^{\circ}$ aoy nīmunt lok desnā uṇhassavijjay phan ț̣mmrañ ${ }^{158}$ smātịy $^{\circ}$ stāp' braḥ dharm jhmoḥ hau uṇhassavijjay/ ka tèjjah ānisańs pān stāp' noḥ höy nin mān āyụ̣ ${ }^{159}$ vèn yị̣n yūr ther thit khsèm khsān nau jā sukh sāpāy ${ }^{\circ}$ hon höy ${ }^{\circ}$ aoy ${ }^{\circ}$ pros satv' jön bīr jön' puon toy ${ }^{\circ}$ tèjjạ ānisańs

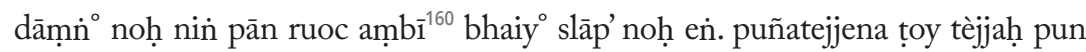
braḥ ța jā thnāṃ ${ }^{161}$ dibb prasör ka āj ghāt' ghāṃn rāṃn rār byādhi maraṇ/

[14-a] ța mān nau khluon puggal' noḥ aoy spöy pāt' pan̉ sīet pān sukh sappāy hon ka hètu ${ }^{162}$ tūcneh mantito rī puggal prus srī anak ța mān prājñā”r prathnā rak 
aoy pān sukh khsèm khsān/ nin pān s-ān magg phal' prayojn aoy pān dāṃñ 3 prakār gịi sammmpatti lokīya ${ }^{163}$ sammmpatti suor sammmpatti nībbān tạ jā thān paraṃmasukh khsèm khsān dhvör aoy / rièn 2 dau kumppìy aoy tẹc löy ${ }^{\circ}$ hoń. dāna phalena tọy nau phal dān pān dhvö mak. yo puggalo rī pugg e ṇā pān aoy ankkar jìvit tūcnoḥ/ höy ${ }^{\circ}$ ka nin mān āyuḥ vèn ther thit khluon ${ }^{164}$ prān sec saṃmpor ța mān rāksmīy srī suostī ānubhābb pāno stāp' braḥ dhaṛm jhmọ̣ hau uṇhassavijjay ${ }^{165}$ noḥ/ en. sako tenasiddhi bhagavato dhammam sutvā mane buddhantarakapaño ${ }^{166}$ vasatilabhatim tile. sako rīy brạ̣ indrār-dhirāj nau supatiț̣hitadevaput nau as ${ }^{167}$ devațā phan dāṃñ hlāy \%

[14-b] noḥ ka pān stāp' brạ̣ dhammadesnār jhmoḥ hau uṇhassavijjayy nau saṃmnāk' braḥ buddh ța jā aṃmcāḥ supatiț̣hitadevaput ka caṃrön āyụ̣ ther thit dau ${ }^{168}$ ṭal' as' braḥ sāsnā braḥ buddh/ gaṃmtèn yön ruoc dau țal' brạ̣ sāsnār brạ̣ sī-āmetrīy ${ }^{\circ}$ bodhisatv'jā ammmcāḥ noḥ hon ka hètu tọy nau tèjjạ̣ phal pun brạ̣ ța jā aṃmcās'braḥ sangh țā jā aṃmcāḥ ${ }^{169} /$ nau sil dān pān dhvö pun juoy ${ }^{\circ}$ ang àtmā neḥ uppaddavā rīy bhaiy 'oggā dāṃn 18 prakār ka raṃmñāp' ralat' ralāy khcāt' khcāy pāt' dau hon. yo pugga-/ lo rīy puggal' e ṇā muoy nin cañ' aoy ang ātmā aoy ${ }^{\circ}$ mān srī jaiy jumnāḥ jhnāḥ ${ }^{170}$ as' satrūv höy aoy mān āyuḥ vèn yīn yūr aoy dhvö tām ganlan̉ brạ̣/ buddh ța jā āmcās' desnār mak noḥ en hon desanāvasāne tu sotāpatiphalādinipāpanisuṃ. uṇhassavijivo luḥ sūrec brạ̣ dharmm visès desnā braḥ buddh ța jā aṃmcāḥ/

[15-a] nām jhmoḥ hau uṇhassavijay noḥ brạ̣ indrār-dhirāj ța jā ddham nau supatițțhitadevaput nau as' devațā phan dāṃñ hlāy pān stāp' nau brạ̣ dhaṛm ${ }^{171}$ brạ̣ buddh ța jā ammmcās' höy ${ }^{\circ}$ ka mān/ citt trek ar sār-dăr sukh sappāy khsèm khsān papūr tām țoy ganlan nai brạ̣ buddh ${ }^{172}$ jā ammcās' anak khlāḥ pān lụ̣ sottā anak khlāḥ pān lụ̣ sakkhidāgā anāgā/ arahatt tām tọy kusal'173 phal pun ang ātmā dīdaiy 2 noḥ en aț̣hi ${ }^{174}$ uṇhassavijayo nițțito. noḥ yön nin sraṭi uṇhassavijayy neḥ miñ/ ka cūl jā paccay' nai dāyak' upāsak' upāsikār niț̣hitā ka cap' paripūr saṃguor ${ }^{175}$ toy nau prakār dāṃñ ammpāl neḥ en hon. ${ }^{\circ}{ }^{176}$ 


\section{Notes}

\section{Parittasamodhānapālì $(1968,306)$.}

2 The Dhammayuttika-nikaya, "the Fratenity of those who stick to the Teaching of the Buddha," is a Theravada monastic fraternity founded in Thailand around 1833 by the future king Mongkut (r. 1851-1868), when he was a bhikkbu. The specific characteristics of this fraternity is the rejection of most of the ritual aspects of Buddhist practices, done in an effort to access the literal understanding of Pāli texts. They are opposed to the old ritualistic traditions of Southeast Asian Buddhism, in particular, the widespread practice among monks of reciting Pāli stanzas without understanding their inner meaning. The Dhammayuttika-nikaya has been introduced in Cambodia around 1850 by King Ang Duong (r. 1848-1860) who had been educated in Siam.

3 Though it is used in most circumstance to name rituals set for ordinary people, the term janmàyu ("age") belongs to the religious or royal vocabulary.

4 màt' dade, literally "free mouth."

5 Manuscript A: One undated bundle of 20 folios (one bearing the title, four blank, and 15 engraved folios); Title: Sec-ktī jùvidān; Script: khmer mūl on five lines; Pagination: 1 to 15 ; Dimension: 50 x $559 \mathrm{~mm}$; Provenance: former library of the Institut Bouddhique. Old rating: 1. 378; Current rating: Bibliothèque EFEO-FEMC - Preah Vanarat Ken Vong $n^{\circ}$ a 4. Manuscript B: One bundle dated 2493 b.e., of 16 folios (one bearing the title, two blank, and 13 engraved folios); Title: jividān; Script: khmer mūl on five lines; Pagination: from Na to İ; Dimension: 50 x 485 mm; Provenance: Vatt mūni suvaṇn, called Vatt jambuh k-èk, Kien Svay district, Kandal Province. Current rating: EFEOFEMC: 012-A-02.08.02.III.1

6 It occurred that, when I fist spoke about Unhissavijjaya in Cambodia, on the occasion of the XIIIth Conference of the International Association of Buddhist Studies, Bangkok, 8-13 December 2002, Her Royal Higness Princess Maha Chakri Sirinthorn very graciously shared a memory. When she was a little girl, she happend to sprain her foot. Modern medicine was useless to heal her sufferings. Then her nanny chanted the Unhissavijjāyagāthā on her leg, and soon the young princess felt relieved.

7 gan' for gàn' prajun.

8 brah ang stec.

9 raluos ph-un: erythrina fusca.

101 yojana = about $16 \mathrm{~km}$ (10 miles); 30 yojana = about $480 \mathrm{~km}$ (300 miles).

11 About $960 \mathrm{~km}$ (600 miles).

12 chāin: "making the noise of cymbals (!)"

13 devaputta, literally "son of a god"; it is, in fact, a divine entity, without divine filiation, properly speaking, corresponding to the "rebirth" in the heaven of the Thirty-three, of a previously human or non human entity, entitled to exhaust in this paradise the fruition of the merits acquired in its previous incarnation. No translation being satisfactory, I keep 
this term as it is written and used in the Khmer text.

14 The "five musical instruments" are traditionally: I) the bin /pən/ ("guitar"); II) the sralai /sralay/ ("palm-billed oboe"); III) the gan /kong/ ("gong"); IV) the sambho / samphao/ ("little drum"); V) the sgar /skor/ ("great drum").

15 avici : textually "without change," that is "the hell of irremissible suffering."

16 The "infernal years" (chnām naruk) each last several thousands of our earthly years.

17 A: "devohiddhiko"; B: "devomahiddhiko."

18 A: "somahārājapubbejāto antamakkhipiyo tegahetvā"; B: "sopanamahārājapubbejāto antapakkhipiyo tegantvā."

19 A: "jātoatțhopapāno"; B: "jāto addho mahāddhano."

20 The four "necessities” (paccăya) are: I) pindapātapaccăya, "almsfood, food”; II) civvarapaccăya: "robes, clothing"; III) senāsenapaccăya: "lodging"; and IV) gilānabhesajapaccăya: "medicine ; medical equipment."

21 ratn kambal < ratta ("red") + kambala "wool clothing," generally considered to be a product of the Nepalese piedmont (Rhys Davids 1921, 189b). In Cambodia, this expression only means "luxury fabrics," which is revealed here by the confusion between ratta / rat / "red" which has been substituted ratna < ratana / rat / "treasure," "precious good."

22 "The disintegration of the 'five aggregate' (pañcakhandha) groups," that is to say "one's death." The five "aggregates" are: rūpakhandha: "corporeality"; vedanäkhandha: "feeling, sensation"; sañ̃akhandha: "perception"; sankhärakhandha: "mental formations," "volition activities"; and vinnnnānākhandha: "consciousness."

23 The name of buddha si-ametri / sə-ametrey/-buddha of the future, fifth and last buddha of the present aeon (pā. bhaddakappa, sk. bhadrakalpa) - is the short form of the usual Khmer designation Si-Äry Metriy/sə-a métrey/, resulting from an influence of a Thai pronunciation - th. / si /> kh. / sə / - from the Sanskrit script Śrī Ariya Maitreya.

24 duon kèr, literally "crystal globe."

25 The "supermundane Laws" (lokuttaradhamma) are the "four path" (magga) end the "four fruition" (phala): sotäpattimagga and sotappattiphala: "the path and the fruition of the stream-entry"; sakadāgāmimagga and sakadāgāmiphala: "the path and the fruition of the once returning"; anāgamimagga and anāgämiphala: "the path and the fuition of the non-returning"; arahattamagga and arahataphala: "the path and the fruition of the arahantship."

26 A: parilāvū; B: parị̄āhū.

27 Uppadavā, read Uppadrab.

28 Uppadava should lead to another translation in Khmer: "the defects," "the vices."

29 The text—supra ff. 10-b-lists only thirteen, or fourteen, "frights" (bhăya) moreover quite in an atypical way. Indeed, some terms seem to be taken in their literal meaning, while in classical literature their use is metaphorical. The "fright of crocodiles" (bhaiy ambī... $\left.k_{r a p} \bar{y}{ }^{\circ} v \bar{a} t^{\prime}\right)$, for example, is taken here, in a naturalistic way, literally, like that of tigers, 
bears or elephants. In the Majjhimanikaya (I, 460), on the other hand, the same "fright of crocodiles" (kumbhillabhaya) metaphorically designates gluttony, etc. Furthermore, this list is derived directly, but in a fanciful way, from that of the ten "dangers" or "obstacles" to the proper exercise of ecclesiastical functions, as enumerated in the Vinaya (Culavagga, p. 429; Mahāvagga, p. 331): I) rājantarāya ("danger from the king”); II) corantarāya ("d. from thieves"); III) udakantarāya ("d. from water"); IV) agyantarāya ("d. from fire”); V) manussantarāya ("d. from men"); VI) amanussantarāya ("d. from non human beings"); VII) vālantaraya ("d. from wild animals"); VIII) sarīsapantarāya ("d. from reptiles"); IX) jivitantarāya ("danger inherent in the vicissitudes of life [illness and death]"); X) brahmacariyantaraya ("Danger of deviating from the practice of morality under the influence of certain impulses").

Moreover, the "long" versions of Jiv-dān provide a complete list of the eighteen "frights" or "fears" (bhăya)-instead of thirty-three, as it is written in the manuscripts-derived, in a way hardly less fanciful, from the canonical model (ms. EFEO-FEMC n ${ }^{\circ}$ 988.III. 5 B. 01. 06. 01, ff. 26 = ke-b, line 3): I) räj [-bhăy] ("fear of king"); II) cor [-bhăy] ("fear of thieves"); III) manuss [-bhăy] ("fear of men") ; IV) amanuss [-bhăy] ("fear of non-human being"); V) aggi [-bhăy] ("fear of fire"); VI) udak [-bhăy] ("fear of water"); VII) pisāc [-bhăy] ("fear of ghosts"); VIII) khānuk [-bhăy] ("fear of blows, bladed weapons"); IX) kantak [-bhăy] ("fear of thorns and arrowheads"); X) nakkhatt [bhăy] ("fear of bad astral conjunctures"); XI) janapad rog [-bhăy] ("fear of diseases contracted in the countryside"); XII) assaddhamm [-bhăy] ("fear of people without faith"); XIII) asandițthi [-bhăy] ("fear of bad people"); $\mathrm{XIV}$ ) asappuris [-bhăy] ("fear of people who respect neither father nor mother, nor the Buddha, nor the Law, nor the Community"); XV) candahatthi assamigagona ("fear of traveling on horseback, or on oxen, or on cruel beasts"); XVI) kukkur abivicchikammani ("fear of dogs, cats, chickens and geese"); XVII) sappadīpi acchattaracchasūkaramahimnsa ("fear of wild animals, bears, tigers, fishing bears, buffaloes, pigs, jackals"); and xviii) yakkharakkhasā ("fear of demons").

30 sotta < sotäpanna "stream enterer," the first rank of "Nobles" (ariyapuggala) in the accession to holiness.

31 sakkadagg < sakadāgāmi : "once returner," the second rank of "Nobles" in the accession to holiness.

32 anagat < anāgāmi : "non returner," the third rank of "Nobles" in the accession to holiness.

33 arahatt < arahant: "worthy one," the fourth rank of "Nobles" in the accession to holiness.

34 B omits "bhagavato arahatto sammāsambuddhassa."

35 A: "mahipandalakamūlè"; B: "pahipandalakamūlè."

36 A: "nai yön dāṃn ' hlāyo"; B: "nai yön phañ dāṃn ' hlāy ."

37 A: "brạ̣ ang gan’ nau löy”; B: "brạ̣ ang gañ' pajun nau löy."

38 In manuscript $A$, the isolated vowell " $U$ " is used as a subscribed "p-Un்."

39 A: "briksā parijāt"; B: "briksā parijātibriks."

40 A: "pragen"; B: "pragen Aoy'." 
41 A: "gambīr braḥ sanganīr"; B: "gambīr mān brạ̣ sanganīy ."

42 A: "mān nān mahāmāyā ța jā buddhamātā"; B: "mān nān mahāmāyā ța jā buddhamātā jā töm.”

43 A: "pìtūc dik cuh mak bī lö ākās"; B: "pìtūc dik dhlāk' bī lö ākās."

44 A: "sapatiț̣hitānāma ahosi"; B: "sapatiț̣hitonāma ahosi."

45 A: "len bhleñ sèp saṃm-pragum tụur-țandrīy”; B: "len̉ bhleñ sèp saṃm ṭūr-țandrīy."

46 B omits "E."

47 B omits "R..."

48 A: "mak bīgroh thā țucneḥ”; B: "mak bīgroḥ thā jā gāthā țucneh."

49 A: "nau tè 7 thñai dīet"; B: "nau khān tè 7 thñai dīet."

50 A: "nin pān cuḥ dau köt”; B: "nin pān cuḥ cāk' dau köt.”

51 A: "atarapāyiti”; B: "atarajāyiti."

52 A: "ātmār"; B "ātmābhāp."

53 B: omits "knun khluon."

54 A: "bhit bhaiy sandhik citt"; B: "bhit bhaiy sandhik sandhai knun citt."

55 A: "dībịn bum nin noḥ gmān löy”; B: "dỉbịn buṃ nin jā buṃ nọ̣ gmān löy."

56 A: “āñ "; B: "atmar."

57 A: "slīek nau spèk"; B: "slīek nau spai."

58 A: "ka hūr ceñ aṃbī khluon”; B: "ka sin hūr ceñ aṃbī khluon.”

59 A: "sariratosedopañcati”; B: "sariratosedopoñcati."

60 A: "pubbanimit dāṃn ${ }^{\circ}$ hlāy yöy”; B: "pubbanimit phan dāṃn ñ hlāy yöyo."

61 A: "saṃțec Indrār-dhirāj”; B: "saṃțec amrin Indrār-dhirāje"

62 A: "mesāmi”; B: "pasāmi."

63 A: "aviciniraye"; B: "avicinniraye."

64 A: "tatha banivassasahassā”; B: "taccā bahunivassasahassā.”

65 A: "phañ dāṃn hlāy yöy"; B: "phan̉ hlāy yöy ."

66 A: "jā dībịn naiy khñummmöy”; B: "jā ditāṃn naiy khñuṃmöy ."

67 A: "devohiddhiko"; B: "devomahiddhiko."

68 A: "lokapāpampāvāhano"; B: "lokapāpampārāhano."

69 A: "mān puṇ saṃmbhār brạ̣ pāramī”; B: "mān puṇ brạ̣ pāramī."

70 A: "lokapāpampavāhano"; B: "lokapāpamparāhano."

71 A: "añ khñum nẹ̣ nin jā dhaṃm”; B: "añ neḥ nin dhaṃm."

72 A: "nikonāț̣ho lokahitā sano anuthasisampadā"; B: "nilonātṭho salokahito sano anuthesisampadā."

73 A: "lok phan dāṃn ' hlāy"; B: "lok dāṃñ hlāy ."

74 A: "braḥ buddh jā aṃmcās'"; B: "rī buddh ța jā aṃmcās.”

75 A: "rī devaputt”; B: "rī devaputt noḥ."

76 A: "gandhamālār phkā bhñīr”; B: "gandhamālār phkā bītor bhñīr."

77 A: "braḥ angan’ trañ' sṭhān E ṇā”; B: "braḥ angan' kun trañ’ sṭhān E ṇā.”

78 A: "thvāy ${ }^{\circ}$ pangamm pūjā"; B: "thvāy ${ }^{\circ}$ pangaṃm praṇaṃ pūjā." 
79 A: "höy ang-guy"; B: "höy ${ }^{\circ}$ mak ańguy."

80 B omits "dauv."

81 A: "jīvit khluon"; B: "jīvit khluon noh."

82 A: "somahārājapubbejāto antamakkhipiyo tegahetvā"; B: "sopanamahārājapubbejāto antapakkhipiyo tegantvā."

83 B omits "gāt'."

84 A: "hèt noḥ pān jā dau köt jā satv' tiracchān”; B: "hèt noḥ pān köt jā satv' tiracchān.”

85 A: "jātoaț̣̂hopapāno"; B: "jāto addho mahāddhano."

86 A: "sukkham vobhavisanti”; B: "sakhavobhavisanti."

87 B omits "thā."

88 A: "purass noḥ anak brạ̣ saṃgh”; B: "purass noḥ ghöñ anak brạ̣ saṃgh.”

89 B omits "dau."

90 A: “tèn māgg' nāa o teḥ țiel braḥ bhikkhu sāmmaṇer”; B: "tèn mān ceñ mak cāṃ teḥ tịel anak braḥ bhikkhu sañgh sāmmaṇer."

91 A: "tèr rak tör sūm"; B: "ceh tè sūm."

92 A: "somanasaṇakkhojātonihetukaṃ”; B: "sopanasaṇakkhojātonihetukaṃ."

93 A: "țūc-mtec ạ̣mcās'”; B: "țūc-mtec jāti mun aṃmcās'."

94 A: "agāravodubhi so buddhaguṇaṃ saṃghaguṇaṃ napāsi"; B: "agāravoduti so buddhaguṇam dhammaguṇaṃ saṃghaguṇaṃ napāsi."

95 A: "mān pandūl”; B: "mān braḥ pandūl."

96 A: "purass noḥ bum kot krèn tèn jer anak brạ̣ sañs"; B: "purass noḥ buṃ kot buṃ krèn tèn nin jer anak brạ̣ sañs."

97 A: "buṃ kot krèn mān tèr tmāḥ"; B: "buṃ kot buṃ krèn mān tèr tmāh.."

98 B omits "viñ."

99 A: "mahārāja Ekasmiṃ”; B: "mahārāja pana Ekasmiṃ.”

100 A: "parisothānaṃ”; B: "parisotatthānaṃ."

101 A: "mahārāj-jöyo devaput neḥ”; B: "mahārājjöy rō devaput neḥ.”

102 B omits "dau."

103 A: "aṃbīr caṃmkār”; B: "aṃbīr dhvör caṃmkār."

104 A: "țoy nau kammavipāk"; B: "țoy vipāk.”

105 A: "ṭa mān prasöröy”; B: "ța mān pan prasöröy”."

106 A: "manuss khvāk'"; B: "manuss bhnèk khvāk'."

107 B omits "diet."

108 A: "samaṇabrāhmaṇakhantā"; B: "samaṇabrāhmaṇakhantātạ̣."

109 A: "Aolokiyamānogaheva pariț̣ho asīditvā tuṇhī ahosi”; B: "Aolokiyamānotehevaț̣̂ā nisīditvā tunhi āhosi."

110 B omits "noh."

111 A: "buṃ nāṃm o bāṛr-țamān khaṃm”; B: "buṃ nāṃm bār khạ̣m.”

112 A: "gāthaha"; B: "gāthahaha."

113 A: "saṃțec”; B: "döbv saṃtec.” 
114 A: "pāpakamm"; B: "pāp."

115 A: "hetabhante"; B: "hetobhante."

116 A: "Uppatitassa"; B: "Uppațitassara."

117 A: "neḥ dhvö"; B: "neḥ nin dhvö."

118 A: "aț̣thabhagavāmukhā"; B: "aț̣thakhobhagavāmukhā."

119 A: "prakap kèv"; B: "pra-ap'kèv."

120 A: "desnā ṭūcneḥ"; B: "desnā sūtr jā gāthā tūcneh.."

121 A: "yak sottapasāda tran'"; B: "yak sottapasāda mak tran'.”

122 A: "Uṇhassavijay țar jā Uvțammm”; B: “Uṇhassavijayo țar jā Uttam.”

123 A: "dhamm neh nin Aoy prayoj"; B: "dhamm nẹ̣ tèn Aoy prayojn."

124 A: "devaputte"; B: "devaputta."

125 A: "brạ̣ dharm uṇhassavijjayya”; B: "braḥ dhaṛm jhmoḥ hauv unhassavijjayya."

126 A: "vicī citt"; B: "vicī dvār."

127 B omits "ca sabbasmā."

128 A: "satrūv phan dāṃñ buon̉ köt"; B: "satrūv phan dāṃñ buoñ köt bhăy."

129 B omits "ktī."

130 A: "ạ̣bī krittiyā"; B: "aṃbī ambör krittiyā."

131 A: "ambī"; B: "bī."

132 A: "pān brạ̣ dhaṛm”; B: "pān stāp' brah dhaṛm."

133 A: "thit ther sranuk"; B: "thit ther nau sranuk."

134 B omits "sappāy."

135 A: "nau lör bhīmān"; B: "nau lör saṃmpatti bhīmān."

136 A: "purass'”; B: "purass'puggal."

137 A: "mān citt"; B: "mān citt kāt'."

138 A: "pān nīmunt"; B: "pān Aoy" nīmunt."

139 A: "sukh"; B: "sukh camrön sukh."

140 A: "samriddhì"; B "siddhi."

141 B omits "jhmoh."

142 A: "devamanussānaṃ nai devatạa"; B: "devamanussānam tạ̄s devațā."

143 B omits "phan."

144 A: "nau lokuttar"; B: "navalokuttar."

145 A: "parị̄āūu ka jrau jrās'”; B: "parị̣âvū ka samanaṃ jrau jrās'."

146 A: "dāmnn " buoñ”; B: "dāṃñ hlāy dāmnn buon."

147 A: "pañ'”; B: "pas' pañ'."

148 A: “Aoỳ rammñāp'”; B: "Aoy tralap’ rammñāp."

149 A: "pān gorabb'”; B: "pān dhvö gorabb'."

150 A: "daduol"; B: "guor daduol."

151 A: "manuss phañ dāṃñ hlāy"; B: "manuss satv phan dāṃñ hlāyo."

152 A: "sukh srī suostī”; B: "sukh prasör suostī."

153 A: "kāy"; B : "bhāyo." 
154 A: "ralut' khcāt'”; B: "ralut' pat' khcāt'."

155 A: "ralat' ralāy"; B: "ralāy o ralat'."

156 A: "rūp ang jivit”; B: "rūp an̉kar jivit."

157 A: "sakkatvā pān"; B: "sakkatvā Aoyo pān."

158 A: "phań țammrañ”; B: "Aoyo phjań țammrañ."

159 A: "nin mān āyuḥ”; B: "nin pān āyuḥ."

160 A: "ruoc ambī"; B: "ruoc raṃlań aṃbī."

161 A: "braḥ ța jā thnāṃ”; B: "brah dhamm ța jā thnāṃ."

162 A: "hon ka hètu"; B: "hon tasma ka hètu."

163 A: "saṃmpatti lokīya”; B: "sampatti manussalok sampatti suorg."

164 A: "ther thit khluon"; "sțher sṭhit khluon."

165 A: "jhmoh hau Uṇhassavijjay”; B: "jhmoḥ Uṇhassavijjayo.”

166 A: "buddhantarakapaño"; B: "buddhenarapañño."

167 B omits "as'."

168 A: "āyuḥ ther thit dau”; B: "āyuḥ yịnn yūr ther thit dau."

169 A: "brạ̣ ța jā aṃmcās’braḥ sangh țā jā aṃmcāḥ̣”; B: "braḥ buddh ța jā ammmcās' braḥ dhaṛm ța jā ammcās' braḥ sangh tạ jā ammcās'."

170 A: "mān srī jaiy juṃnāḥ jhnāḥ”; B: "mān srī suostī jaiy juṃnāḥ jhnāḥ.”

171 A: "stāp' nau braḥ dhaṛm”; B: "stāp' nau ras' braḥ dhaṛm."

172 A: "ṭoy ganlañ nai brạ̣ buddh”; B: "țoy nau ganlan̉ brạ̣ buddh.”

173 A: "țoy kusal'”; B: "toy nau kusal'."

174 A: "atthini”; B: "atthi."

175 B omits "samguor."

176 Manuscript B has a colophon that does not appear in version A: "neh sec-ktī jīvidān niyāy 'bi devaputr cap 'bon. lok bhikkhu vìt cār duk samrāp 'vatt bodhi antèt Aoy ${ }^{\circ}$ grap' 5 bān 'brah vassā. cār cap 'nau thinai 2 13/7 chnām khāl dosăk ba. sa... 2493 brah vassā. sūm pān sec-ktī sukh dāmnn pì prakār Aoy 'pān dān 'brah se-āmetrì kampì ghlāt. sec-ktī jīvitdān. sanlik aksar 13 Uinka NA MO." "Here is finished the text of the Jividana, which speaks about a devaputta. Venerable monk [named] Vit inscribed it to be kept at the Vatt Bo Andet until the five thousand years [of the religion of the Buddha] are completed. Fully inscribed on Monday, the 13th day of the waning moon of the seventh month, the year of the Tiger, second of the decade, the year 2493 of the Buddhist Era [Monday October 9, 1950 A.D.]. He required the five forms of happiness to experience the teachings of the Buddha Si-ämetri without fail. Jividàn, 13 paginated leaves [according to the syllables of the formula] $\mathrm{Na}$ Mo." 


\section{References}

\section{Primary Sources}

Manuscript A: Bibliothèque EFEO-FEMC - Preah Vanarat Ken Vong n a 4 , undated: One bundle of 20 folios (one bearing the title Sec-ktī jividän, four blank, and 15 engraved folios).

Manuscript B: EFEO-FEMC: 012-A-02.08.02.III.1, dated 2493 b.e. (1950): One bundle of 16 folios (one bearing the title jividann, two blank, and 13 engraved folios), from Vatt mün̄i suvanṇ, Kien Svay district, Kandal Province.

\section{Secondary Sources}

Parittasamodhänapälī samräp' 'gana: dhammayutti (1967 [reprint in 1997]).

Phnom Penh : Institut Bouddhique. 